\title{
EL CÓMIC PERIODÍSTICO EN AMÉRICA LATINA
}

\author{
Stephanie Abaroa
}

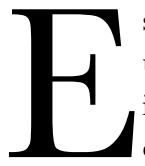

ste formato de periodismo cubre noticias de no ficción o eventos reales utilizando la estructura de cómics. Es una combinación de palabras e imágenes dibujadas. Aunque el modo de contar historias visualmente ha existido desde los inicios de la comunicación, el uso de cómics para cubrir los acontecimientos de la vida real es cada vez más utilizado. Este formato es a menudo comparado con el periodismo literario porque los dos tienen muchas características en común.

El propósito del cómic periodístico no solo es transmitir información, sino narrar una historia teniendo en cuenta que los gráficos son tan importantes como el contenido. Asimismo, el periodismo literario hace énfasis en relacionar ideas y emociones para transmitirlasasuaudiencia.Elcómicperiodísticocombinalasconvenciones estructurales del cómic tradicional con las del periodismo literario.

$\mathrm{Al}$ igual que el periodismo literario, el cómic periodístico tiene el inconveniente de no poder ser publicable rápidamente por su proceso de producción. Se requiere de tiempo para la creación de los distintos gráficos y la comprobación de datos. Sin embargo, las narrativas gráficas recientes están ofreciendo formas innovadoras de contar historias sobre hechos reales . Un ejemplo es la revista de cómics llamada "Mamá!" que se imprime en Italia desde el 2009y "Symbolia”, una revista digital de cómics de periodismo creada para tablets y iPads. 
Joe Sacco es considerado como uno de los pioneros de este formato. El caricaturista estadounidense ha ganado varios reconocimientos a lo largo de su carrera. Estuvo nominado al "Los Angeles Times Book Prize" por su trabajo "Sacco's Footnotes in Gaza” ((2016). Sacco se especializa en contar historias gráficas del Medio Este. Él viajó a las ciudades de Sarajevo y Gorazde cerca del final de la Guerra de Bosnia y produjo una serie de informes sobre Palestina. Los comics "Safe Area Goražde" y "The Fixer" fueron incorporados en su libro titulado "War's End". Esto le hizo acreedor de una beca en "Guggenheim Fellowships" en abril del 2001. "Safe Area Goražde" ganó el Premio Eisner a la mejor novela gráfica original en 2001.

Los cómics de no ficción contemporáneos reflejan la herencia del “comix” underground de los años 1960 y 1970. Esto nace como una alternativa a los cuentos de superhéroes dirigidos comercialmente a un público adolescente. "Las obras de los escritores estadounidenses de cómic no periodístico tales como Harvey Kurtzman, Robert Crumb y Harvey Pekar ayudaron a definir el potencial del cómic para contar historias basadas en hechos reales", afirma la "Fundación Nieman", un organismo que busca impulsar el interés de los jóvenes a este género, con el apoyo de la Universidad de Harvard.

A principios de los 90's, el caricaturista americano Art Spiegelman ganó dos Premios Pulitzer con su cómic "Maus: Historia de un sobreviviente". Su caricatura narra la historia de la relación de Spiegelman con su padre, un sobreviviente del Holocausto, y el testimonio de su padre. "Maus", escrito y dibujado hace más de trece años, demuestra la capacidad de los cómics para narrar distintos aspectos históricos desde una perspectiva personal (Spiegelman, 2016). La década de 1990 fue también la edad de los cómics autobiográficos, unos largos relatos centrados en la angustia existencial de la vida personal de sus autores, en su mayoría jóvenes.

"Los cómics son uno de los medios más accesibles del mundo", recalca Willem de Graeve, Director de comunicación del Centro Belga del Cómic. "Aquí, en Bélgica, estamos más en la comunicación visual". Agrega que para un país que sufre una división lingüística tan pronunciada, "la comunicación visual es mucho más eficiente que la comunicación tradicional”, indicó en el portal digital Político de Europa.

\section{Latinoamérica}

El trabajo de las y los historietistas latinoamericanos tiene, desde siempre, intereses artísticos muy cercanos a lo social. Los autores se desprendieron fácilmente de los estigmas de los súper héroes y crearon un universo literario gráfico propio en cuanto a historieta se refiere.

Las dictaduras que asolaron a países como Brasil, Argentina y Chile, los conflictos bélicos y guerras civiles en los países centroamericanos como Nicaragua, el Salvador y Guatemala, los movimientos armados revolucionarios en Perú y Colombia, así como las férreas condiciones de pobreza, problemas económicos, políticos y sociales 
han hecho de los caricaturistas latinoamericanos verdaderos cronistas de su tiempo (The Cult, 2015).

En sus obras de gran diversidad temática y estilística, se ve reflejada una América Latina convulsa, conflictiva, alterada y herida. En los trazos de cada historietista, se puede observar el compromiso, la intención y el anhelo de mostrar otra Latinoamérica, la de la esperanza, la que se reconstruye, la que va marcando las pautas de significativos cambios sociales; la imaginativa, fantástica, de ciencia ficción, de humor entrañable, de sensibilidad creativa, de hilarantes conflictos cotidianos, la dedicada al público infantil, la educativa y la periodística (Pacarina del sur, 2015).

Los primeros trabajos de periodismo en historieta se ubican por su cercanía con géneros literarios como la biografía y la autobiografía. Uno de los proyectos más sentidos y sensibles de este tipo de periodismo en cómic es el conjunto de las historias recopiladas en el proyecto "Historietas por laidentidad" (2012). Esta iniciativa recoge breves historias de vida de personas (abuelos, hermanos, tíos) que buscan a algún miembro de su familia desaparecido en la dictadura argentina. El proyecto convocó a diversos caricaturistas para que, a través de su narrativa, cuenten la historia de bebés desaparecidos y las personas que los buscan, breves historias de vida, biografias fugaces de personas a quienes los militares arrebataron su vida y la de sus hijos e hijas.

La campaña de difusión fue lanzada por la organización de "Las abuelas de Plaza de Mayo" en Argentina. Esta iniciativa bien podría entrar en la corriente de historietas de tipo biográfico, pues para hacer estas breves historias se recurrió a archivos documentales y visuales y, en muchos casos, entrevistas a las personas que buscan a sus familiares. Desde otra perspectiva más autobiográfica, está una de las representantes más contundentes de este género en América Latina, Paola Gaviria, mejor conocida como Power Paola. Su trabajo autobiográfico "Virus Tropical" (2013) narra las tensiones, vida cotidiana y cultura en la década de los 80 y 90's cuando ella, en plena adolescencia, transitaba entre Ecuador y Colombia.

Otra de las características del periodismo en historieta de América Latina es el trabajo en colectivo, ya sea con artistas latinoamericanos o de Europa y Estados Unidos (Todo historietas, 2016b). Un ejemplo de esto es el artista visual colombiano Felipe Camargo Rojas. Entre sus novelas gráficas se encuentran "Rulfo, una vida gráfica" (2014), un relato sobre la vida y obra del escritor mexicano Juan Rulfo. El guion fue de su compatriota Óscar Pantoja y la gráfica es de Camargo. Estos artistas se unieron a otros ilustradores para realizar la novela gráfica biográfica "Gabo, memorias de una vida mágica” (2013), en conjunto con Miguel Bustos, Tatiana Córdoba y Julián Naranjo. Esta novela gráfica se mete en la intimidad de la vida y obra del literato colombiano Gabriel García Márquez, más conocido como "Gabo".

"El periodismo se trasladó al mundo de los comics", argumenta el periodista experto en cómic, Diego Marinelli. "Nada de superhéroes ni fantasías para adolescentes: el 


\section{Stephanie Abaroa}

'cómic periodismo' es un género para lectores adultos, que toma los recursos clásicos de la crónica (entrevistas, investigación de archivo, fuentes, vivencias en primera persona) y los combina con el despliegue gráfico de la historieta”, agregó el medio Rumbos Digital (2015).

Es necesario mencionar a una de las mujeres famosas del humor gráfico argentino, Maitena Burundarena. Esta dibujante incursionó en el cartoon político de género, con temas como "Mujeres Alteradas, Superadas y Curvas peligrosas" en donde explora la condición prejuiciada de lo femenino y expone las contradicciones de ser mujer en una sociedad contemporánea (Todo historietas, 2016a). El humor, la autocrítica y un dibujo sencillo y honesto, componen el potente trabajo de Maitena.

En Uruguay, la revista "Guambia” es una de las más importantes en cuanto a humor gráfico se refiere. Ahí publicaron humoristas gráficos como Ombu y Tunda Prada.

En Perú también existe una gran tradición en historieta y cartoon político. Gracias al trabajo de investigación del caricaturista Miguel Arturo titulado "La caricatura política como fuente documental" (2012), se han dado a conocer algunos nombres de periodistas involucrados en el cómic como: Julio Málaga Grenet, Vizcarra, Alcántara La Torre, Osorio, Pencil, Cano Romero, Moreno, Heli, Holguín, Cisneros entre otros.

El sociólogo mexicano, Armando Bartra, describe en el contexto revolucionario mexicano, a los litógrafos de prensa, quienes hacían una forma de periodismo crítico a través de las imágenes, aunque también la vida cotidiana se representaba en historieta. Tal es el caso del grabador mexicano José Guadalupe Posada, quien elaboró viñetas en forma de notas periodísticas sobre temas populares: el asesinato de tal personaje, la pelea en el barrio, el problema del robo, el adulterio, entre otros. Esta especie de crónica de lo cotidiano unía el grabado, el periodismo y la sátira política.

En el caso de los caricaturistas venezolanos se encuentra Luis Britto, quien también es escritor y ensayista. Esto le ha permitido desarrollar una forma de humor muy gráfica y simbólica. Trabajó para la publicación "El sádico ilustrado" en donde se dieron cita grandes historietistas y humoristas gráficos venezolanos como Salvador Garmendia, Ignacio Cabrujas, Miguel Otero Silva, entro otros.

Otro ejemplo peculiar es "Pictoline". Esta organización planteó una nueva forma de convertirse en un medio de información y noticias visuales útiles, rigurosamente tratadas para ser divertidas y con colores pasteles. Todas deben ser capaces de ser digeridas por la audiencia en segundos. El mexicano creador del blog "Cinismo Ilustrado" y director de "Pictoline", Eduardo Salles, señaló en su cuenta personal de Twitter que para producir las diferentes imágenes siempre está "épicamente informado". Añadió que espera que todas las personas que ven las distintas infografias, gifs o videos los disfruten "tanto como nosotros haciéndolo" (2015). 
Entre los retos del periodismo en historieta, se encuentran aquellos vinculados con la profesión periodística, es decir, no se debe olvidar que uno de los objetivos primordiales del periodismo es informar. Ese principio no debería ser soslayado ante la impronta de la anécdota personal, o la experiencia íntima. Es menester de los periodistas en historieta otorgarle un lugar privilegiado a la información del hecho noticioso de relevancia social, sobre todo para exponer las voces que comúnmente son silenciadas. Otro de los desafíos del periodismo de cómics es el trabajo multidisciplinario, con dibujantes, periodistas, diseñadores y otros profesionales para conjuntar sus saberes y construir productos de periodismo en historieta cada vez más complejos.

Con historia y raíces ancladas en la realidad social del continente, el cómic periodístico en América Latina solo espera más espacio en los medios tradicionales. 


\section{Referencias}

Marinelli, Diego. (22 de junio de 2015). El periodismo se trasladó al mundo de los cómics. Rumbos Digital. Extraído desde http://www.rumbosdigital.com/ culturas/el-periodismo-se-traslado-al-mundo-de-los-comics

Pacarina del sur. (2015). Periodismo en historieta en Latinoamérica, propuestas para cambiaral mundo. Extraído desde http://www.pacarinadelsur.com/51-dossiers/ dossier-15/1117-periodismo-en-historieta-en-latinoamerica-propuestas-paracambiar-al-mundo

Sacco, J. (2016). Fantagraphics. Artist Bio - Joe Sacco. Extraído desde http:// fantagraphics.com/flog/artist-bio-joe-sacco/

Salles, E. (27 de julio de 2015). [Comentario de Twitter]. Extraído desde https:// www.google.com.ec/?gfe_rd=cr\&ei=YP3HWIugJ6rI8Af73YHwAw\&gws_rd= ssl\#q=eduardo+salles+\%E2\%80\%9C\%C3\%A9picamente+informado $\% \mathrm{E} 2 \%$ 80\%9D+twitter\&*

Spiegelman, M. (2016). La segunda Guerra. Maus, de Art Spiegelman. Extraído desde http:/ / www.lasegundaguerra.com/viewtopic.php?f=21\&t=12355

The Cult. (2015). Historia del cómic latinoamericano. Extraído desde http://www. thecult.es/Comic/historia-del-comic-latinoamericano.html

Todo historietas. (2016a). La historia del comic en la Argentina. Extraído desde http:// www.todohistorietas.com.ar/historia_argentina_1.htm

Todo historietas. (2016b). La historia del comic en los países latinoamericanos. Extraído desde http://www.todohistorietas.com.ar/historia_latinoamerica.htm 



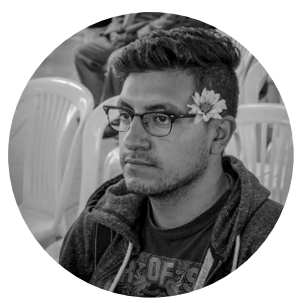

Jorge Cisneros es artista nacido en Ecuador, egresado de Artes Visuales en la Universidad Católica del Ecuador. "Como creador visual veo el mundo desde mi perspectiva particular, y articulo un discurso que llegue al espectador en forma de colores y líneas. Este es el lenguaje que propongo y lo expreso estéticamente." 


\section{Capítulo I $\begin{array}{lllllll} & \text { I } & \mathbf{E} & \mathbf{T} & \mathbf{N} & \mathbf{A} & \mathbf{M}\end{array}$}

La guerra de Vietnam se libra entre los años de 1955 y 1977 , el conflicto bélico busca impedir la reunificación de Vietnam bajo un gobierno comunista. Por un lado Vietnam del Sur, respaldado por los Estados Unidos. Y por otro, el Viet Cong y Vietnam del Norte, respaldados por China y Rusia. Se estima 1 ' 400.000 muertes entre civiles y militares.

Ejércitos de diferentes naciones movilizan millones de militares a la zona de conflicto, entre ellos se encuentra Leonard Matlovich, Sargento de las Fuerzas Aéreas. 

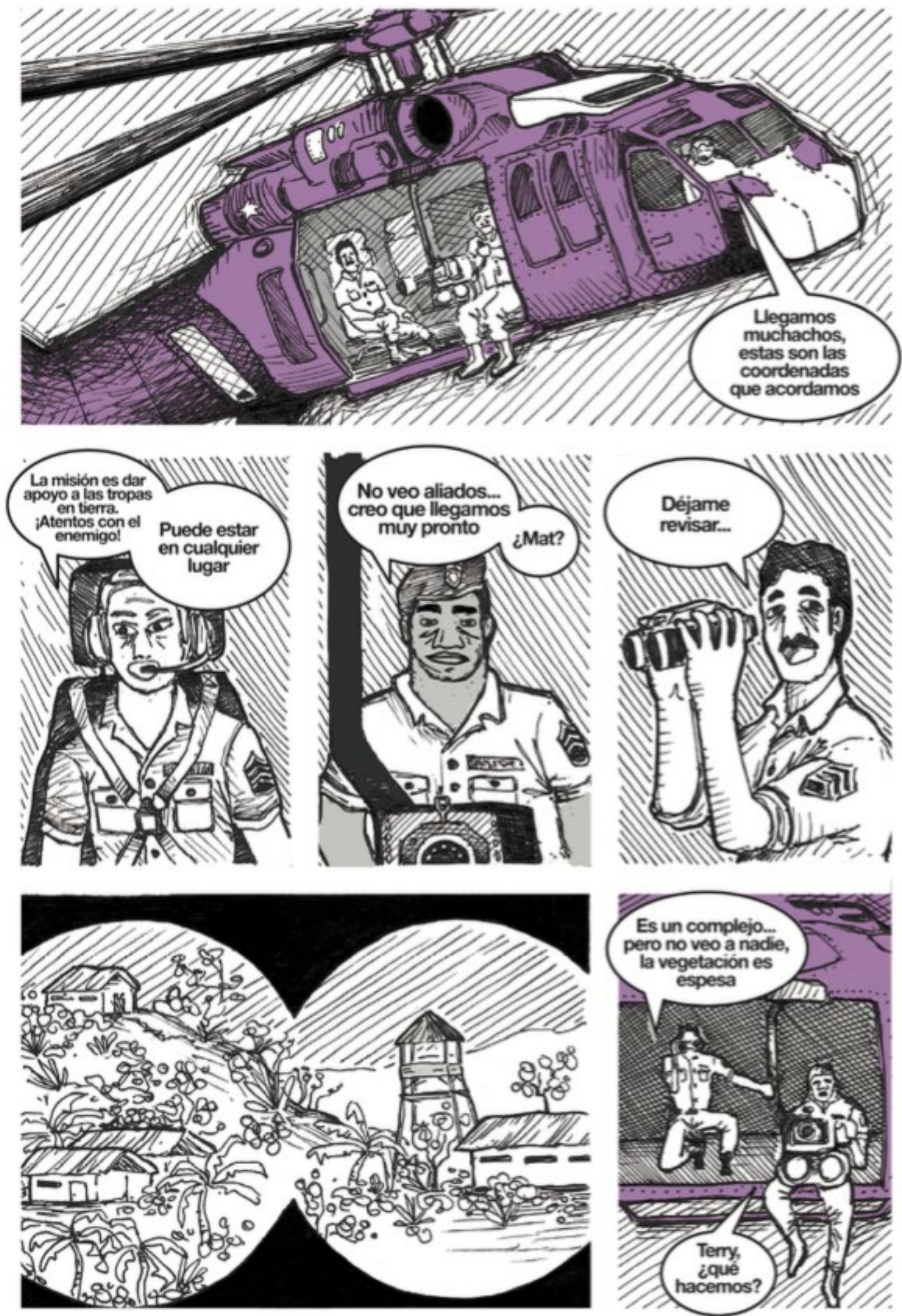

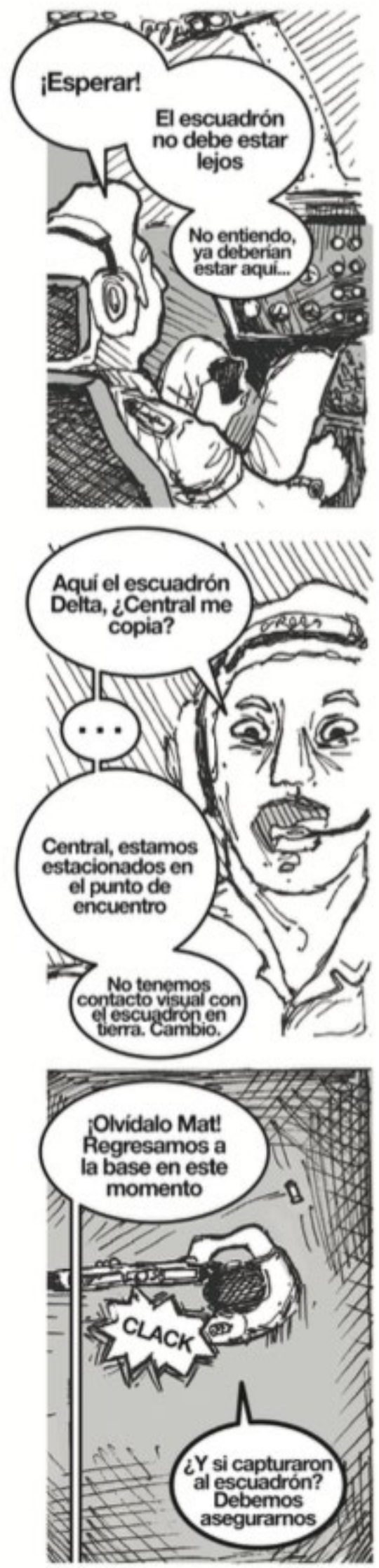

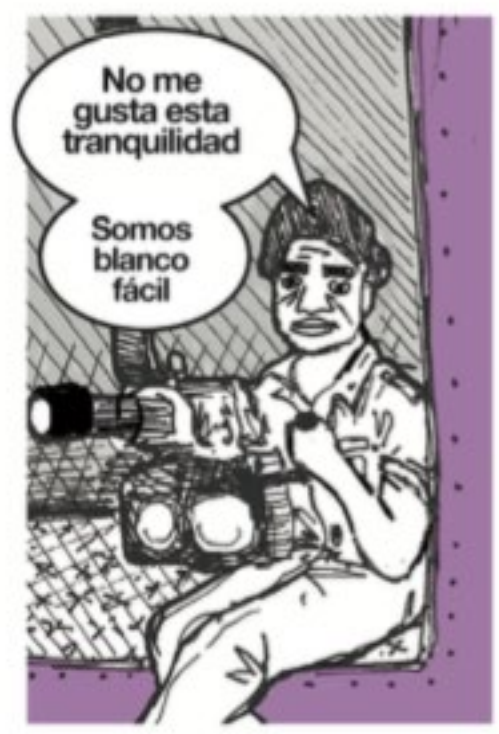

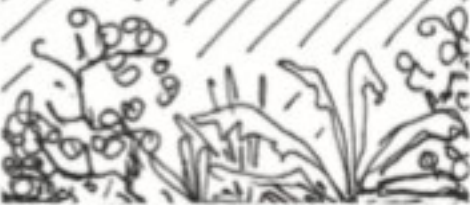
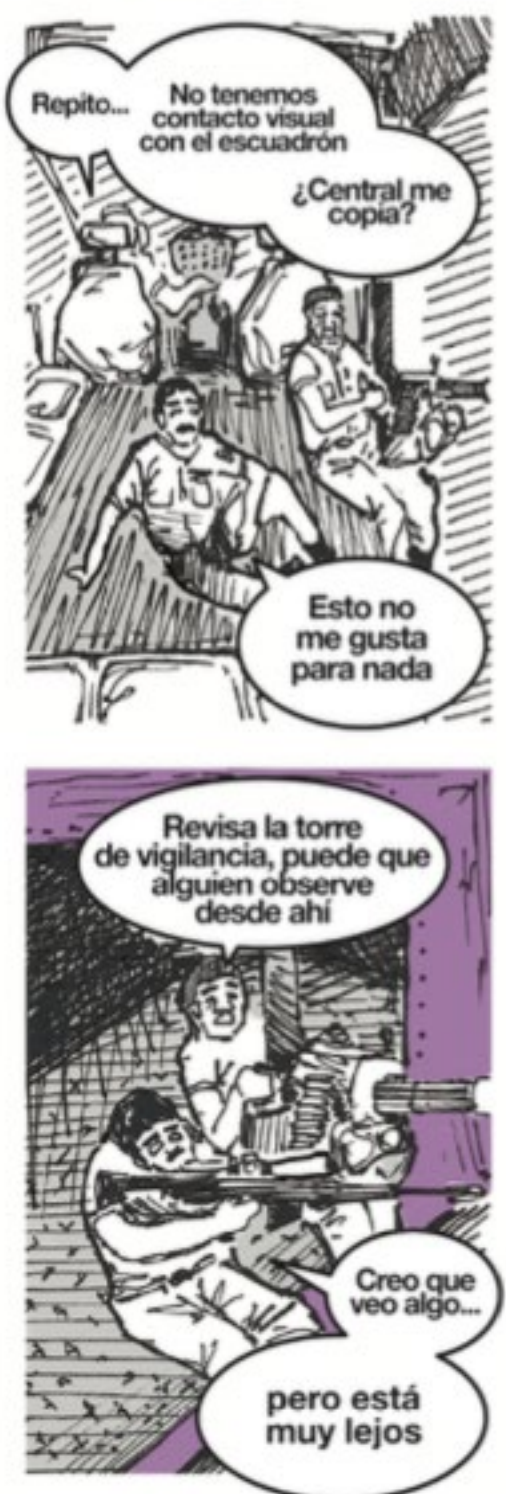
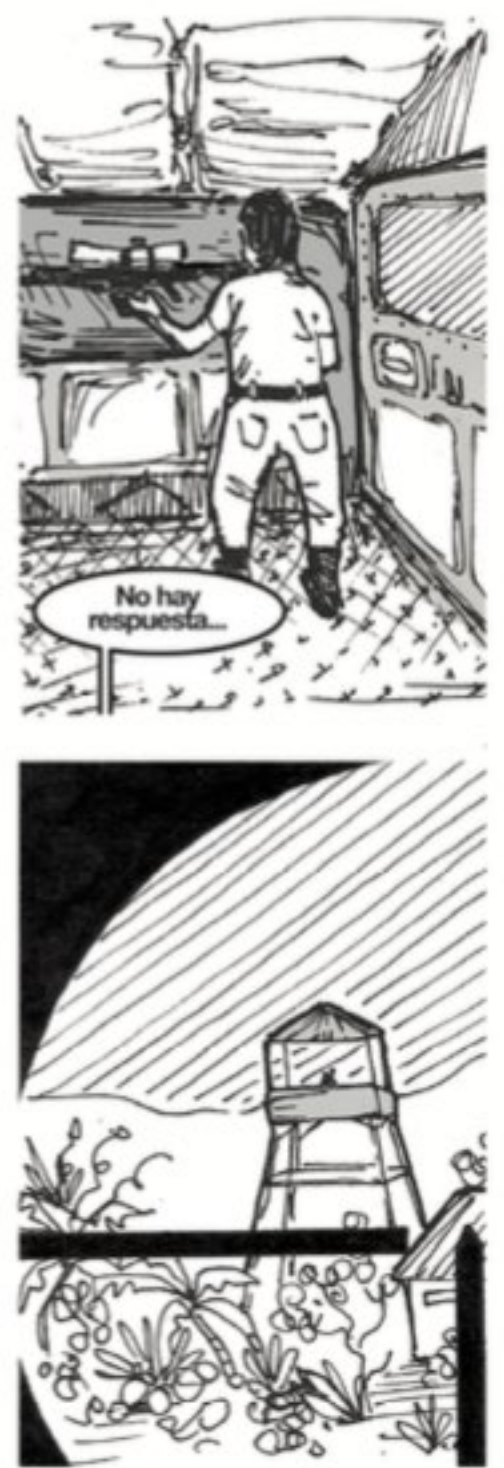
3

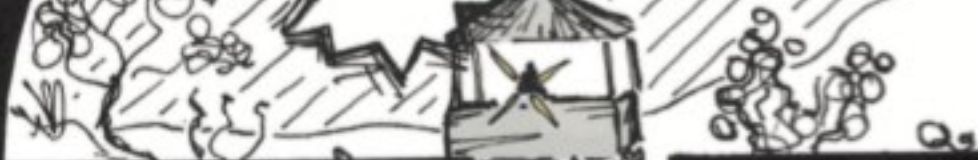

.

of 3 ,

P

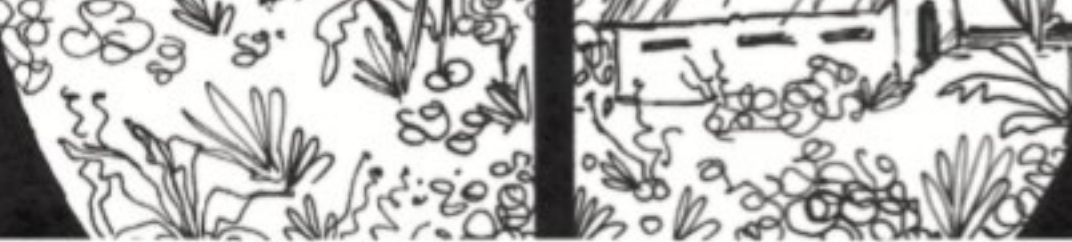

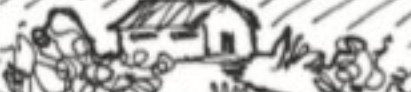

20 $10 \%$ M

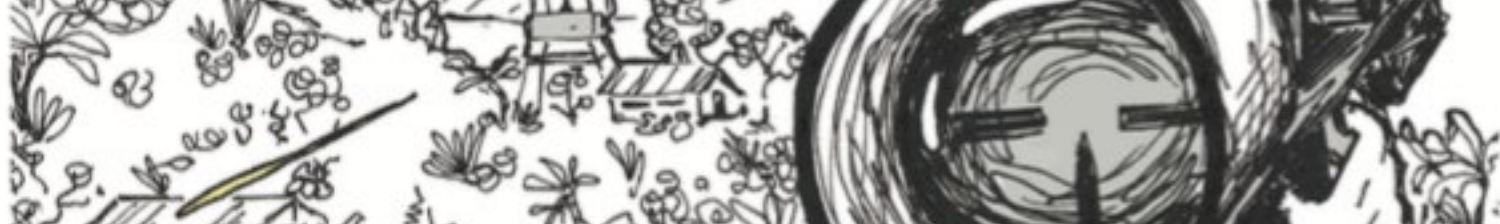

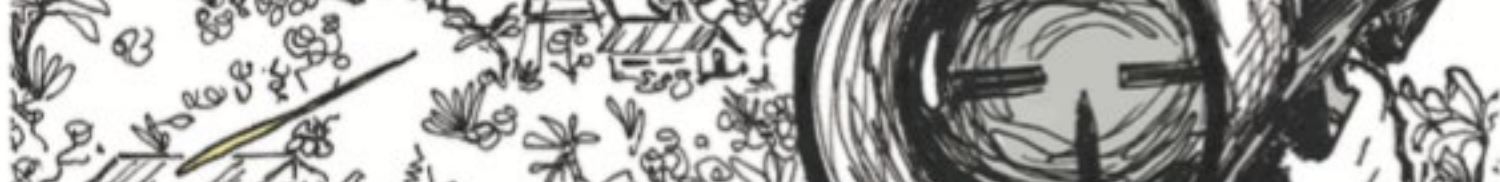

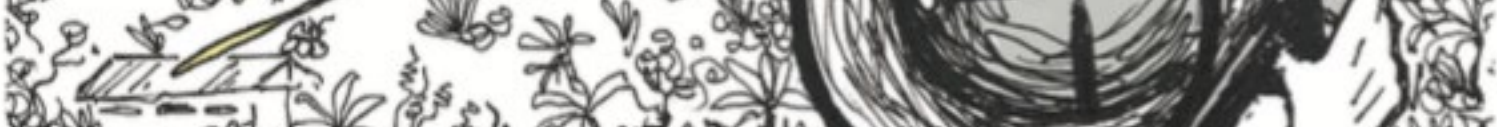
- 1401 5. 5.200

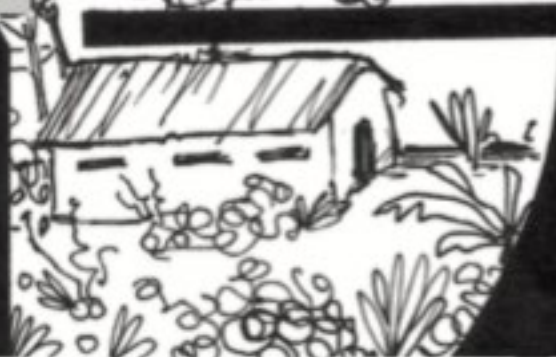
785 T.
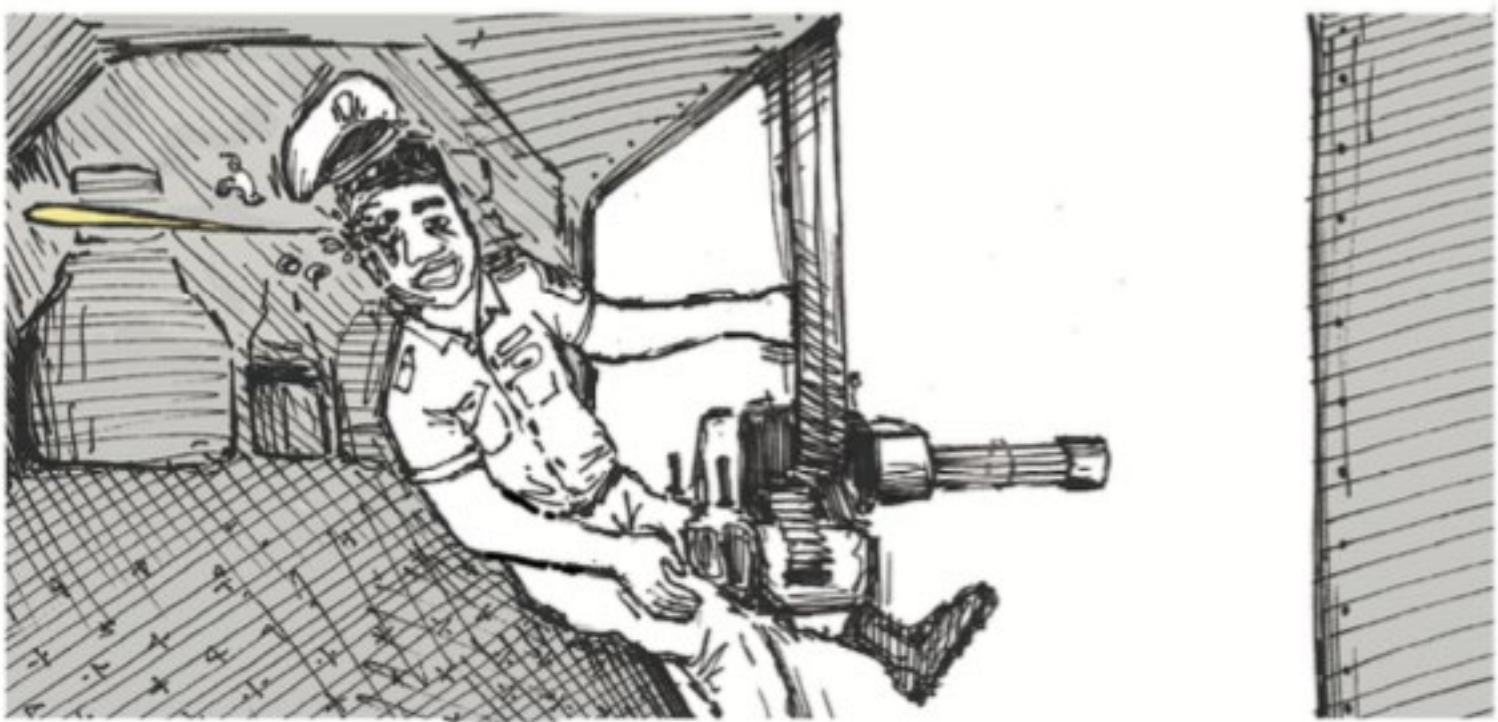


\section{Capítulo II $\begin{array}{lllllll}\text { F } & \mathbf{R} & \mathbf{A} & \mathbf{N} & \mathrm{K} & \text { I } & \mathbf{E}\end{array}$}

El30 deabrilde 1975, después de 48 horas de enfrentamiento, la ciudad de Saigón cae frente al feroz ataque articulado por las Fuerzas de Vietnam del Norte. Las milicias extranjeras y locales ahí asentadas huyen de la ciudad por los medios posibles. El Sargento Matlovich participa de la evacuación.

Leonard quién es condecorado con el Corazón Púrpura por su accionar durante la guerra, pierde a amigos cercanos. Nadie es ajeno a la brutalidad de la guerra y las secuelas le perseguirán para siempre. 

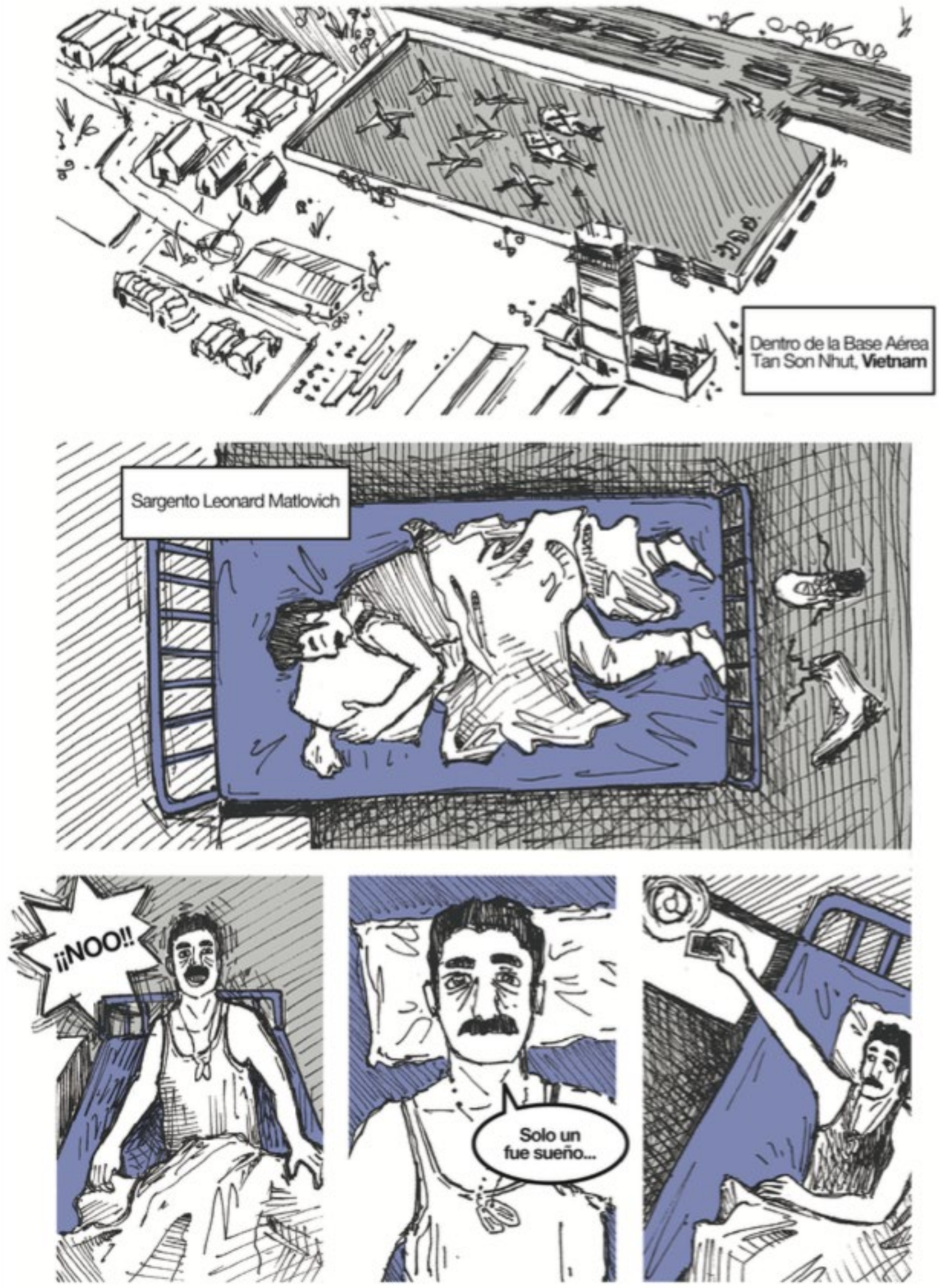

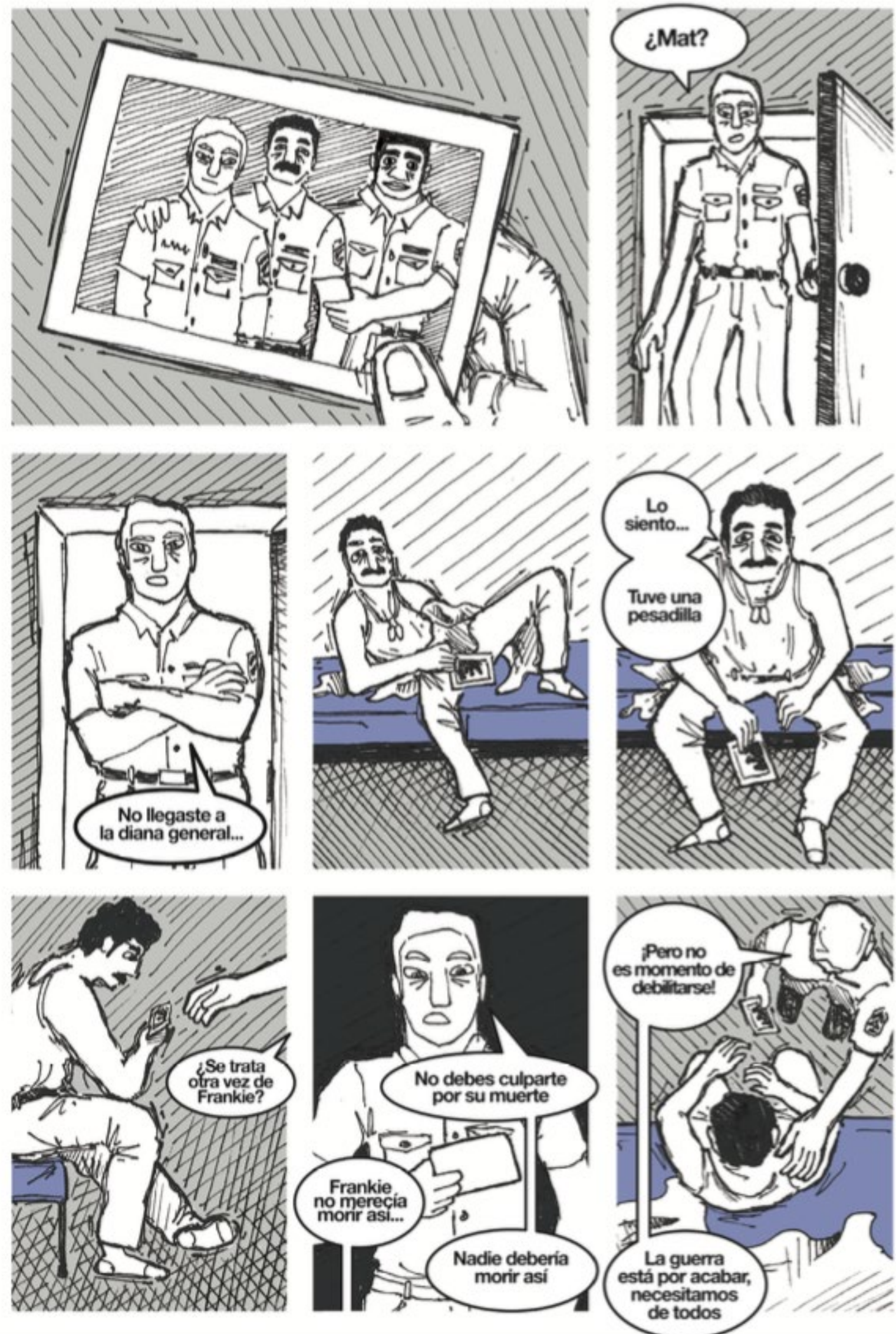

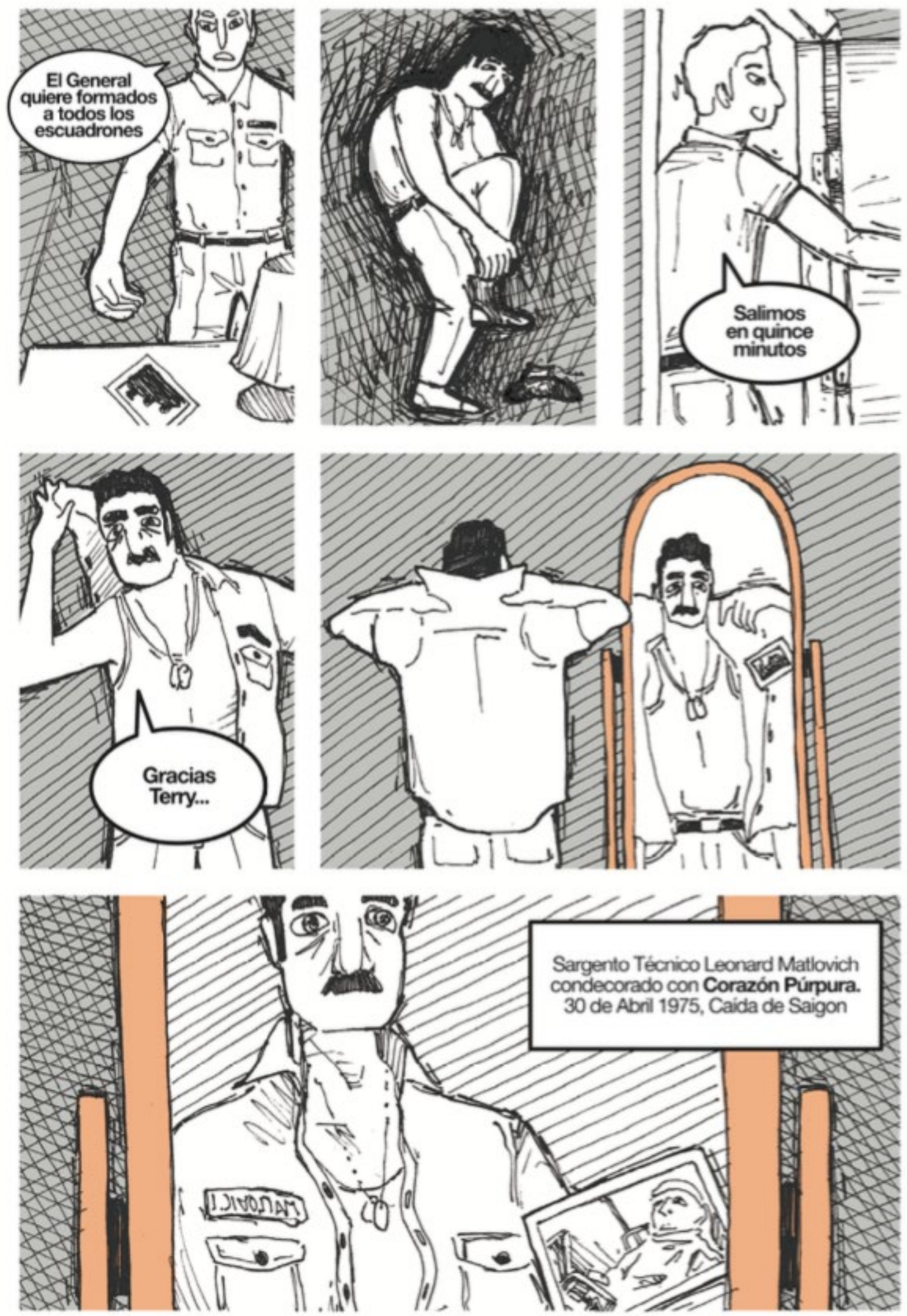


\section{Capítulo III \\ A D D L E S T O N E}

De regreso en Estados Unidos, Matlovich intenta continuarcon su vida después de la guerra. Esto mientras diversos procesos sociales evidencian intolerancia hacia los homosexuales diariamente.

Matlovich lucha por encontrarse a sí mismo mientras los fantasmas del pasado le atormentan. Al mismo tiempo encuentra respaldo en personas cercanas quienes le apoyan.

Mat es homosexual y está dispuesto a contárselo al mundo. 

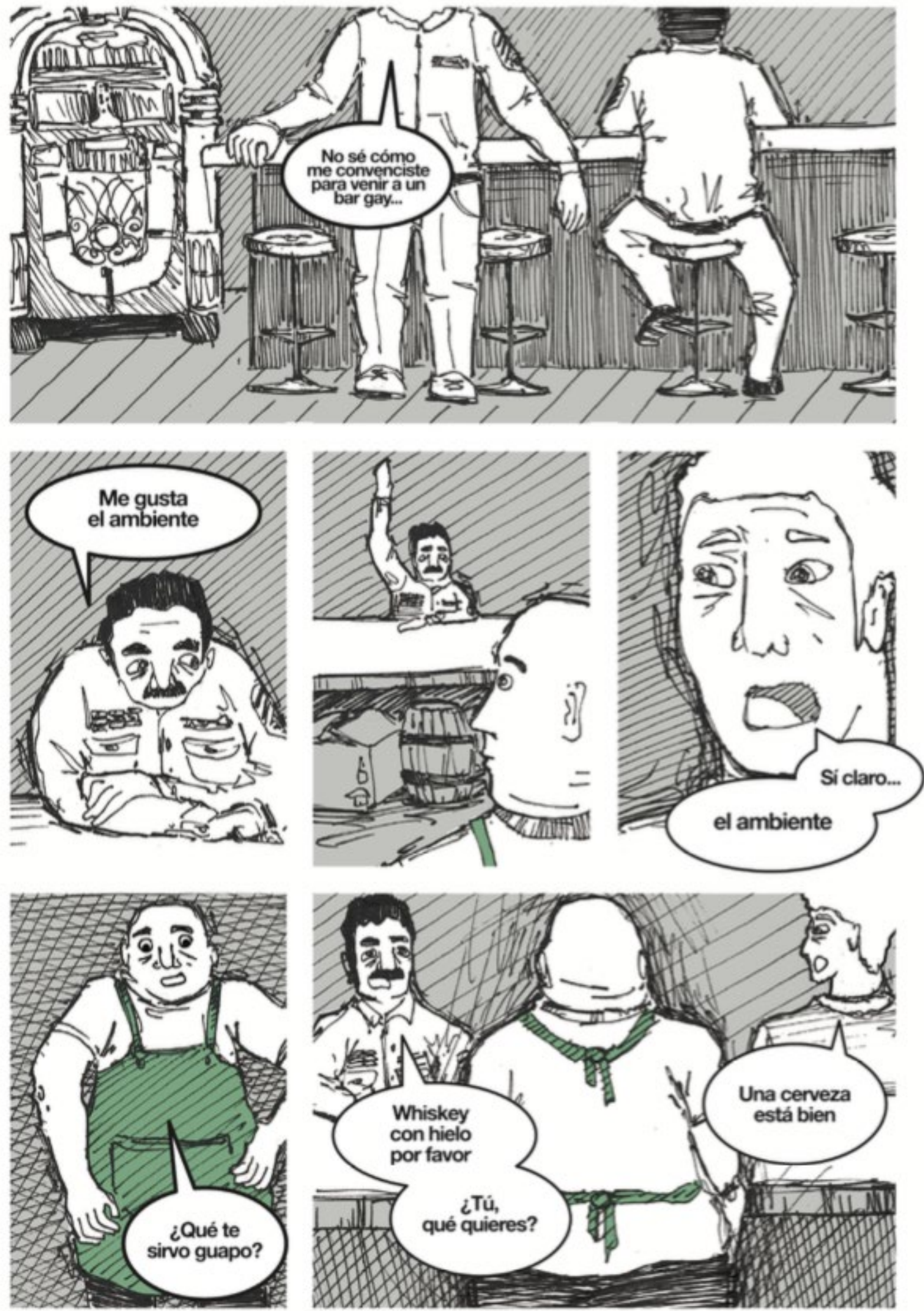

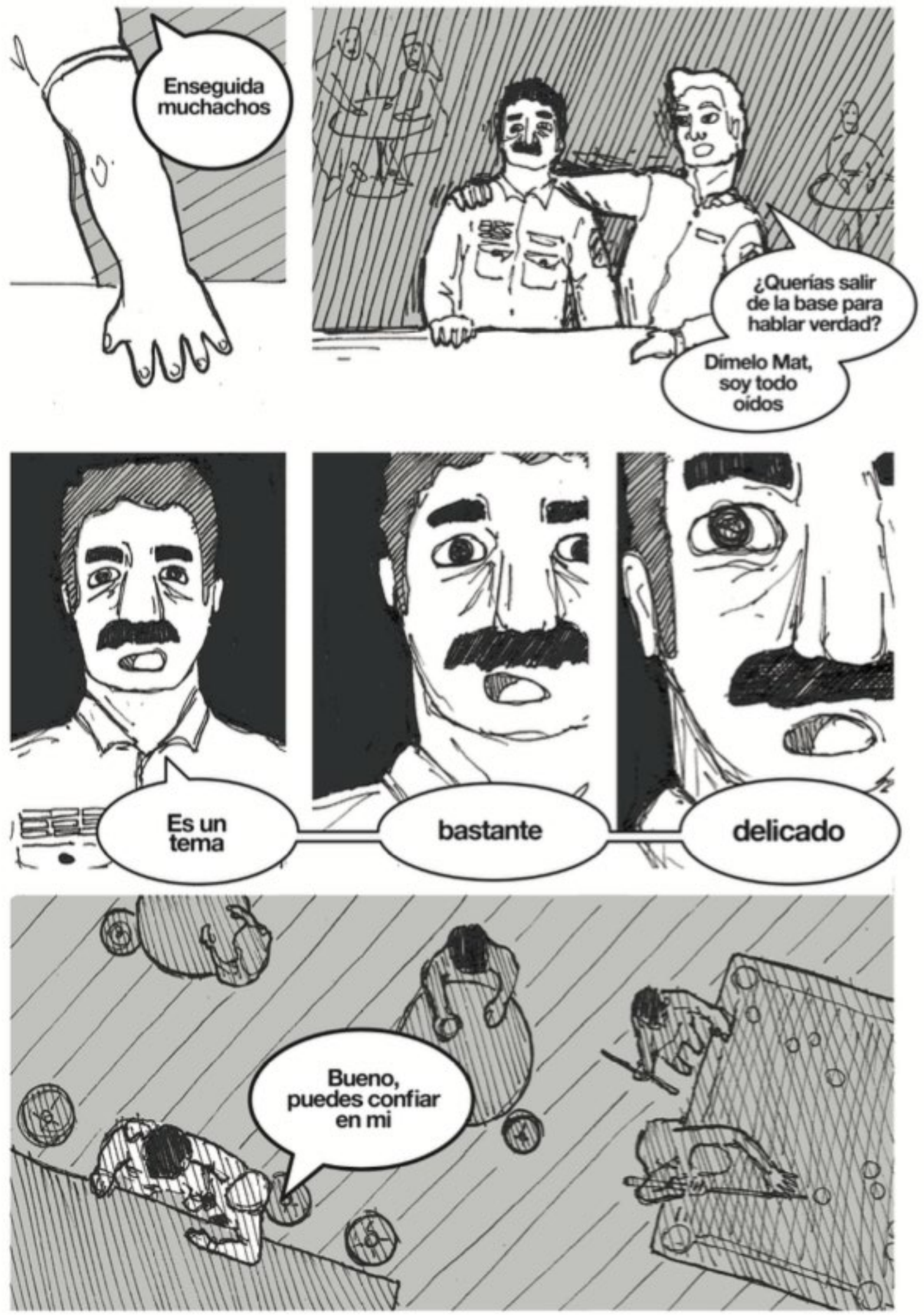

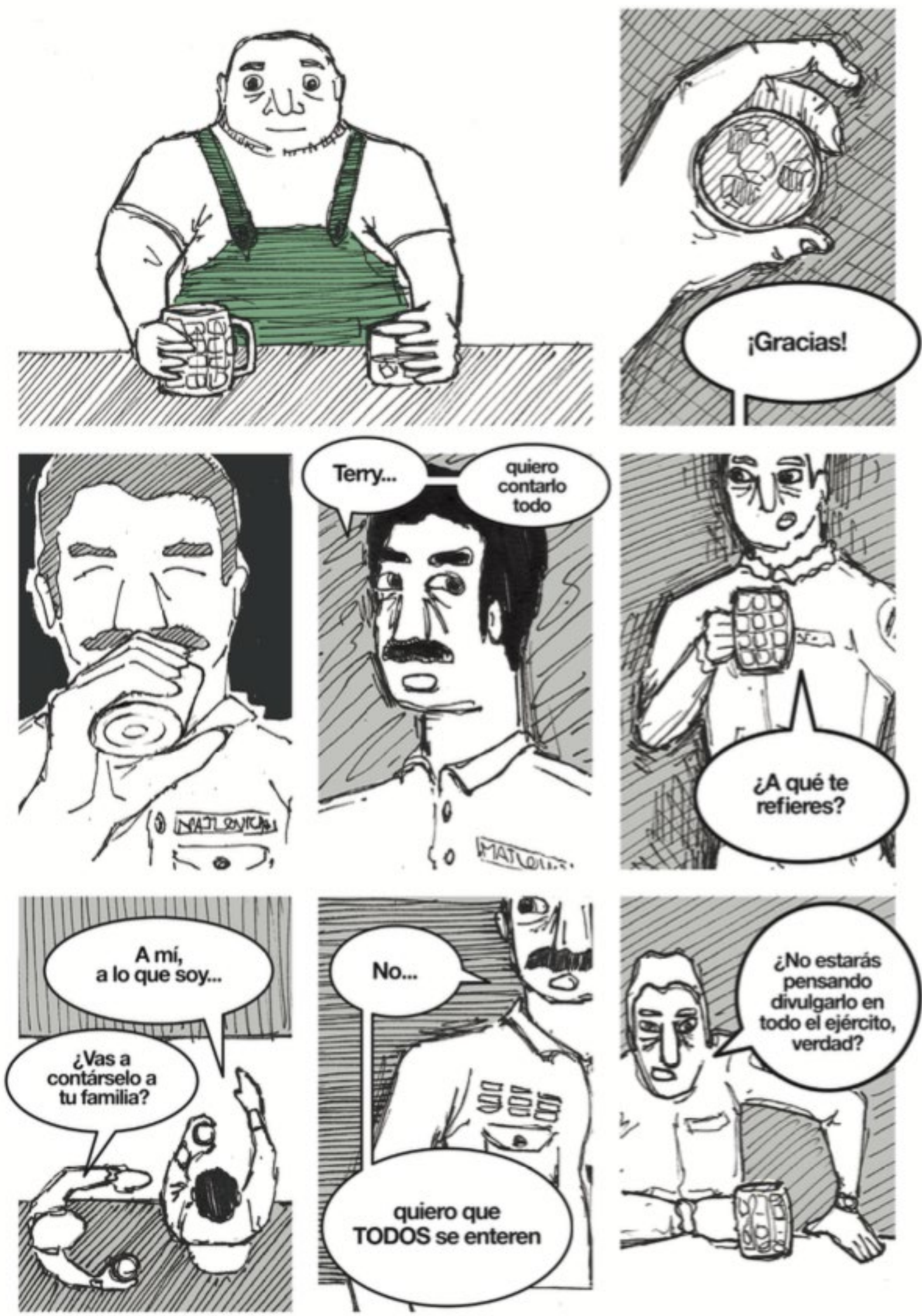

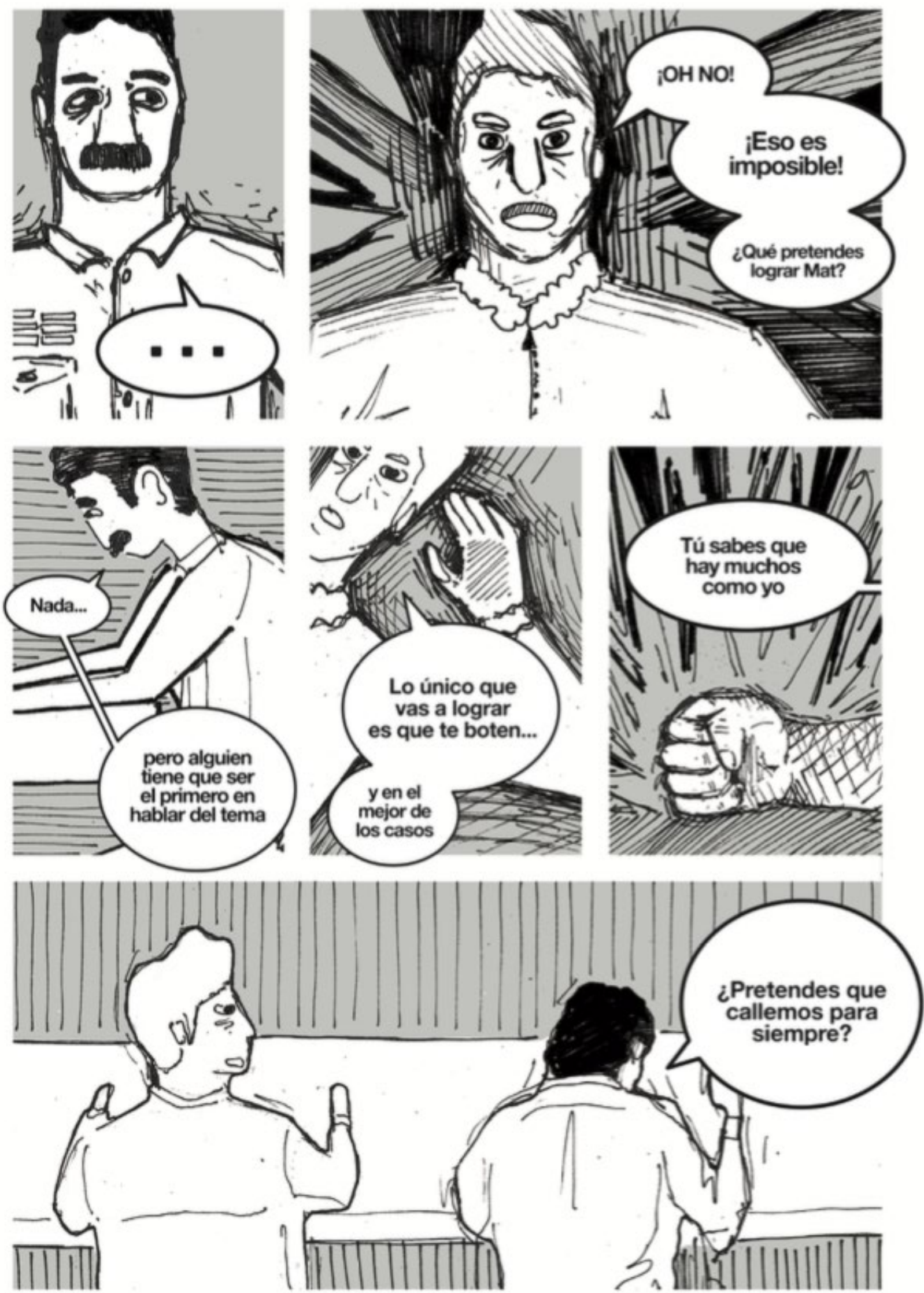

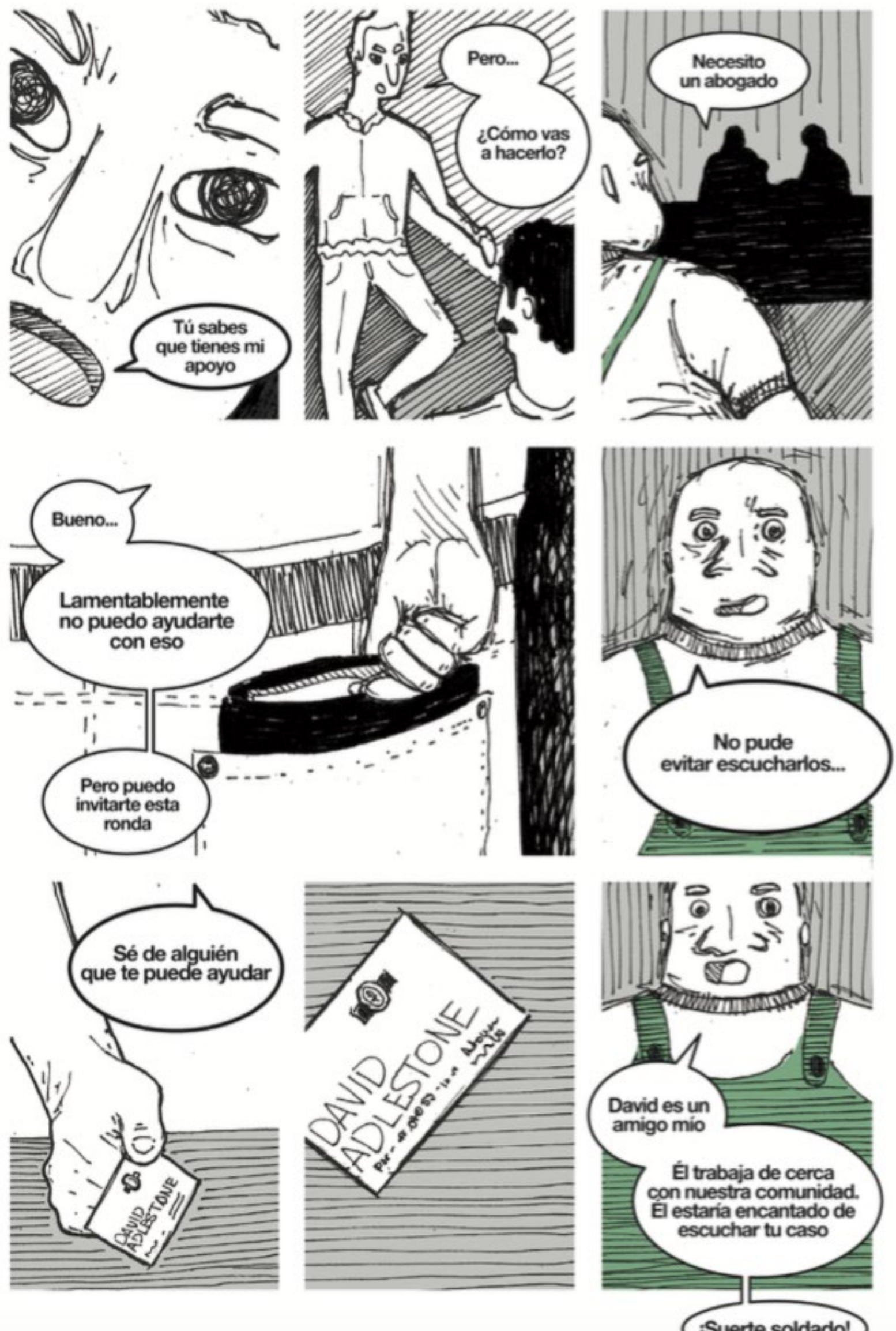


\section{Capítulo IV $\begin{array}{lllllll}\mathbf{L} & \mathbf{A} & \mathbf{C} & \mathbf{A} & \mathbf{R} & \mathbf{T} & \mathbf{A}\end{array}$}

Es el año 1975. David Addlestone trabajaba como abogado en la Unión de Libertades Civiles de Estados Unidos y había estado en búsqueda de un soldado homosexual a quién representar. Esto con el fin de exponer su historia y sentar precedentes para hacer frente a la intolerancia que existe por parte del ejército hacia los soldados homosexuales.

En Matlovich encontró el caso perfecto. 

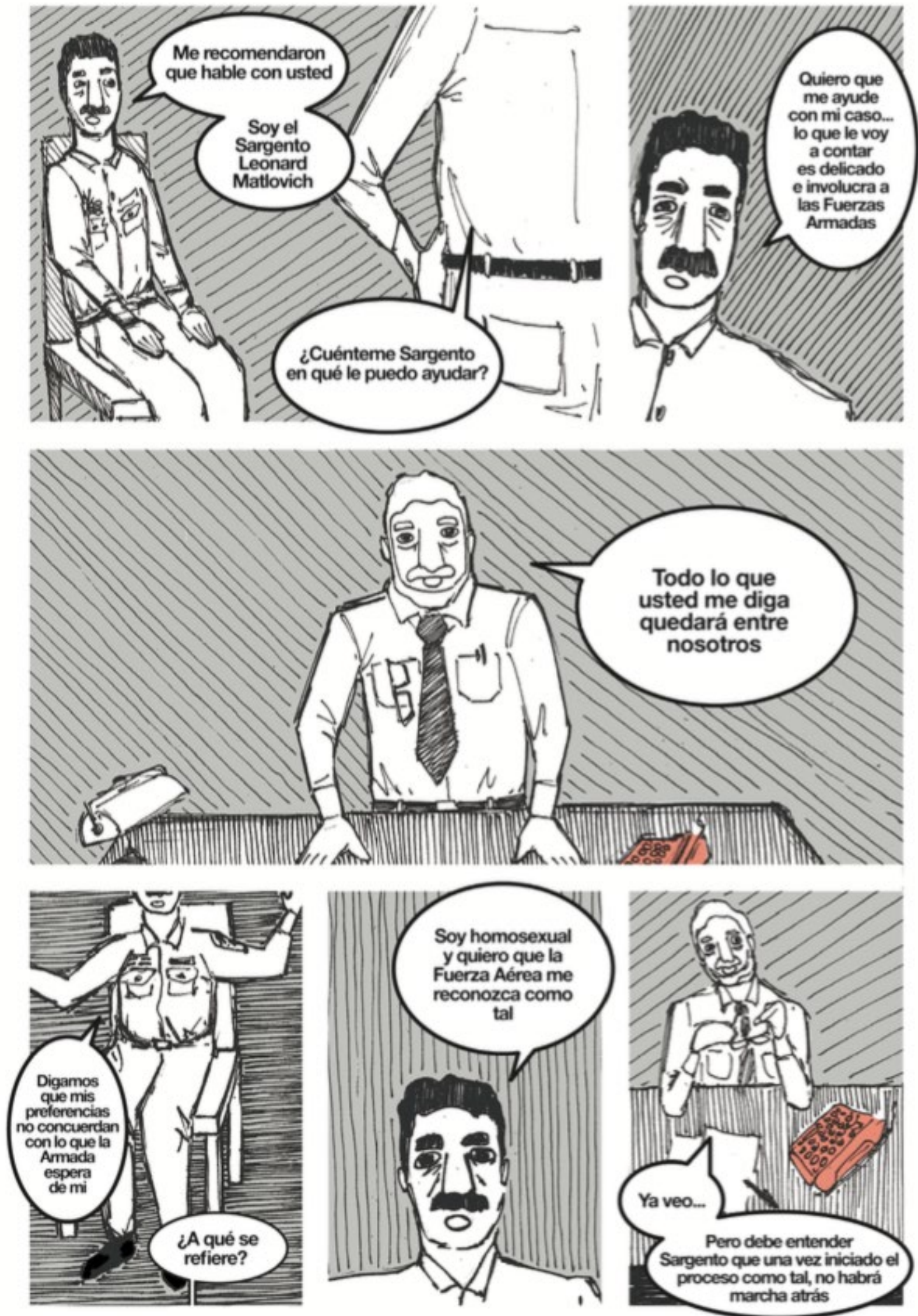

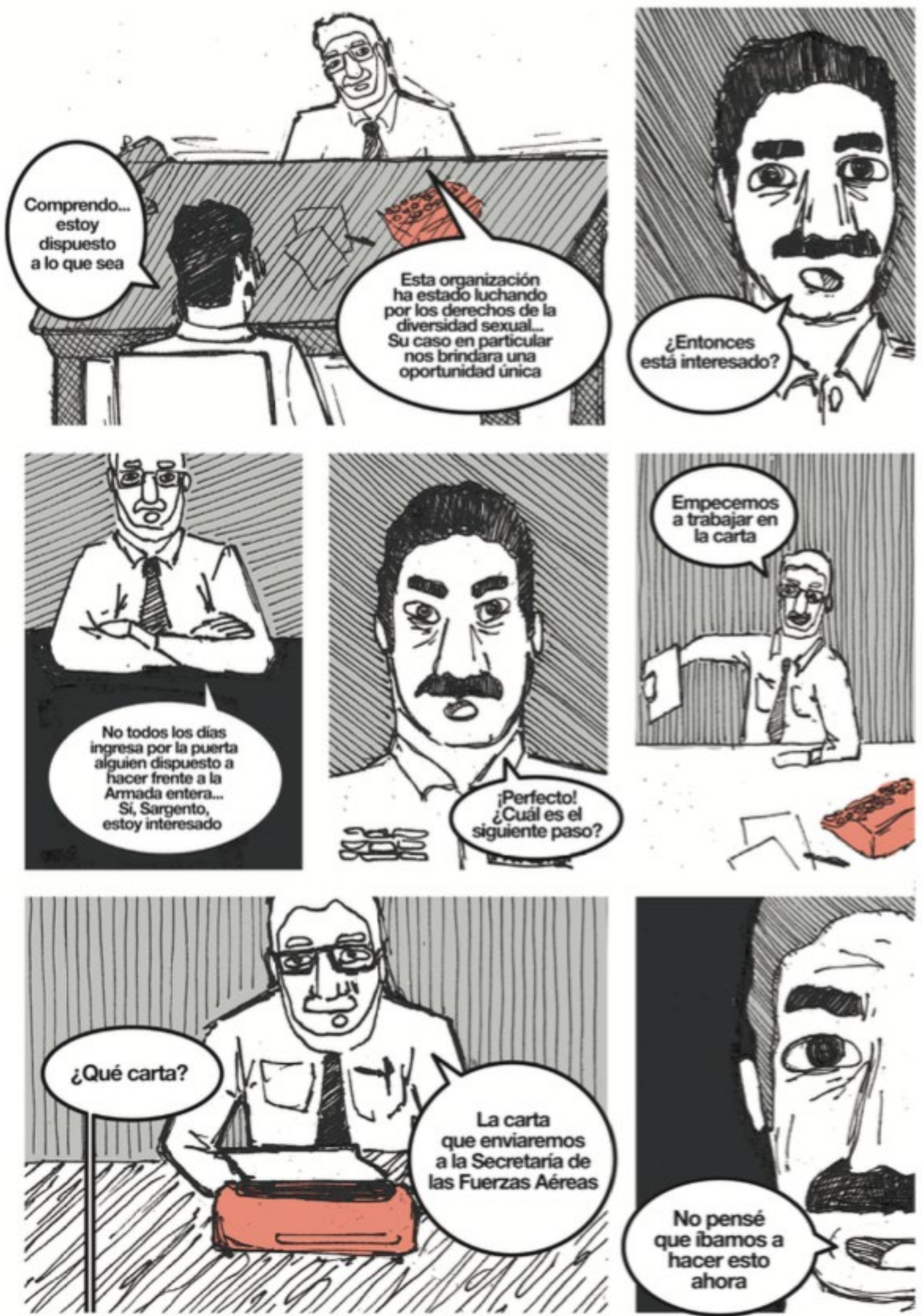


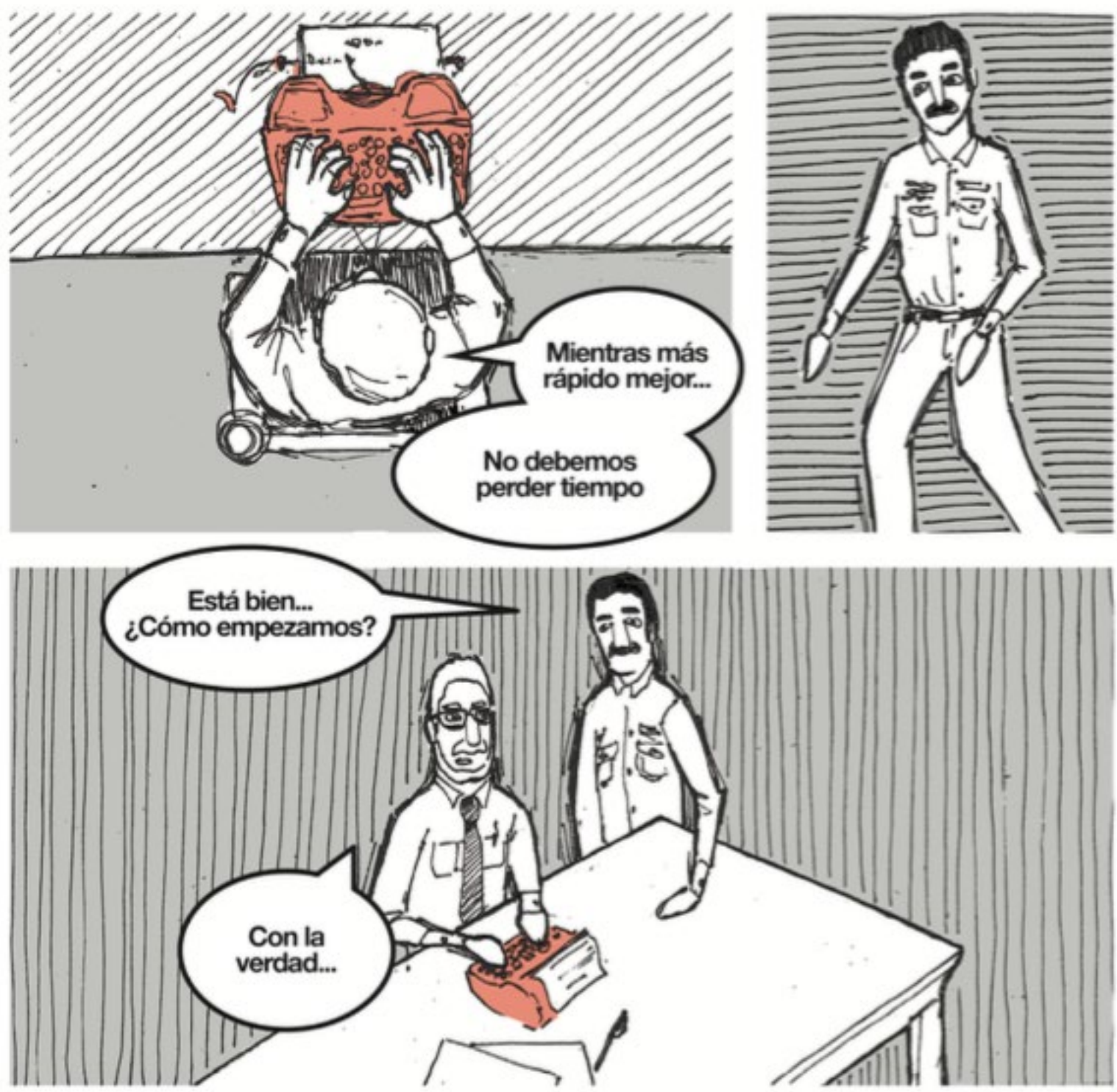




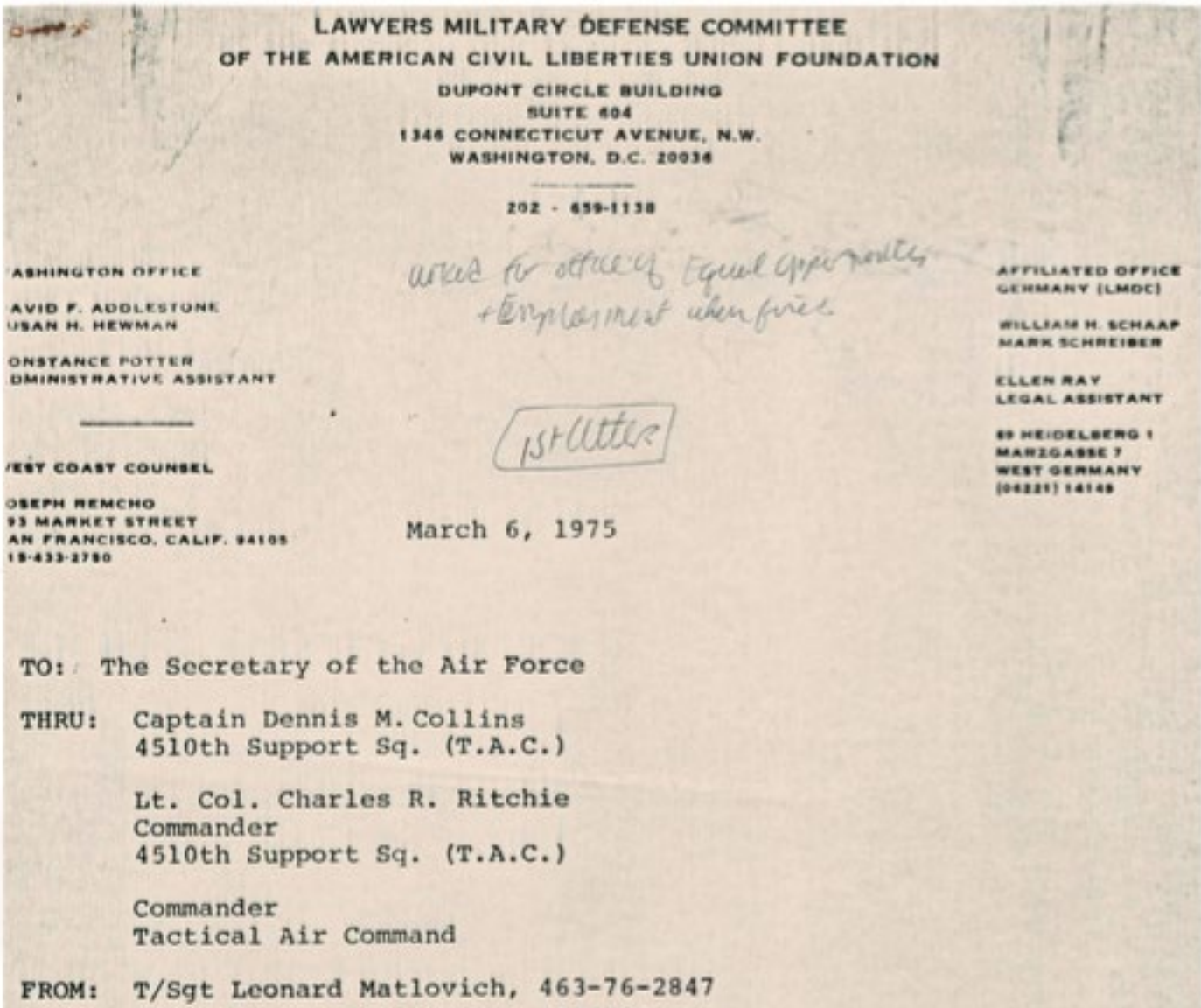

1. After some years of uncertainty, I have arrived at the conclusion that my sexual preferences are homosexual asopponed to heterosexual. I have also concluded that my sexual preferences will in no way interfer with my Air Porce duties, as my preforences are now open. It is therefore requested that those provisions in AFM 39-12 relating to the discharge of homosexuals he waived in my case.

2. I will decline to answer any specific questions concerning the functioning of my sex life, for AFM 39-12 as currently in effect could subject me to a less than fully honorable discharge. However, I will be glad to answer any questions concerning my personal ife if reasons are given detailing how the questions relate to specific fitness and security concerns rather than the generally unconstitutional provisions of AFM 39-12 relating to the discharge of homosexuals. If more-specific criteria other than the notion that homosexuald $\mathrm{are}_{\mathrm{m}} \mathrm{flly}$ unqualified for service in the Air Force can be shown as basis for questioning, I will answer the appropriate questions.

3. Before any specific questions are addressed to me about this matter my attorney, David F. Addlestone, 1346 Connecticut Avenue N.W. , Suite 604 , Washington, D.C. 20036 , requests that he be notified.

4. In sum, I consider myself to be a homosexual and fully qualified for further military service. My almost twelve years of unblemished service supports this position.

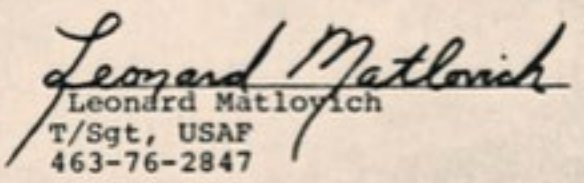




\section{Capítulo V BAJA DESHONORABLE}

Al enterarse del contenido de la carta los superiores de Mat deciden que no es apto para el servicio. Proceden entonces a darle la baja deshonorable, lo que desencadenará años de lucha por parte de ambas partes. Todo esto desde el ojo atento del público que vive el caso desde la cobertura que brindan diferentes medios de comunicación.

David y Mat no pierden tiempo, para que este caso se vuelva público acuden a diferentes medios de comunicación, como el canal CBS, el periódico New York Times. Además, Mat aparece en la portada de la revista Time, declarando "Soy homosexual". 

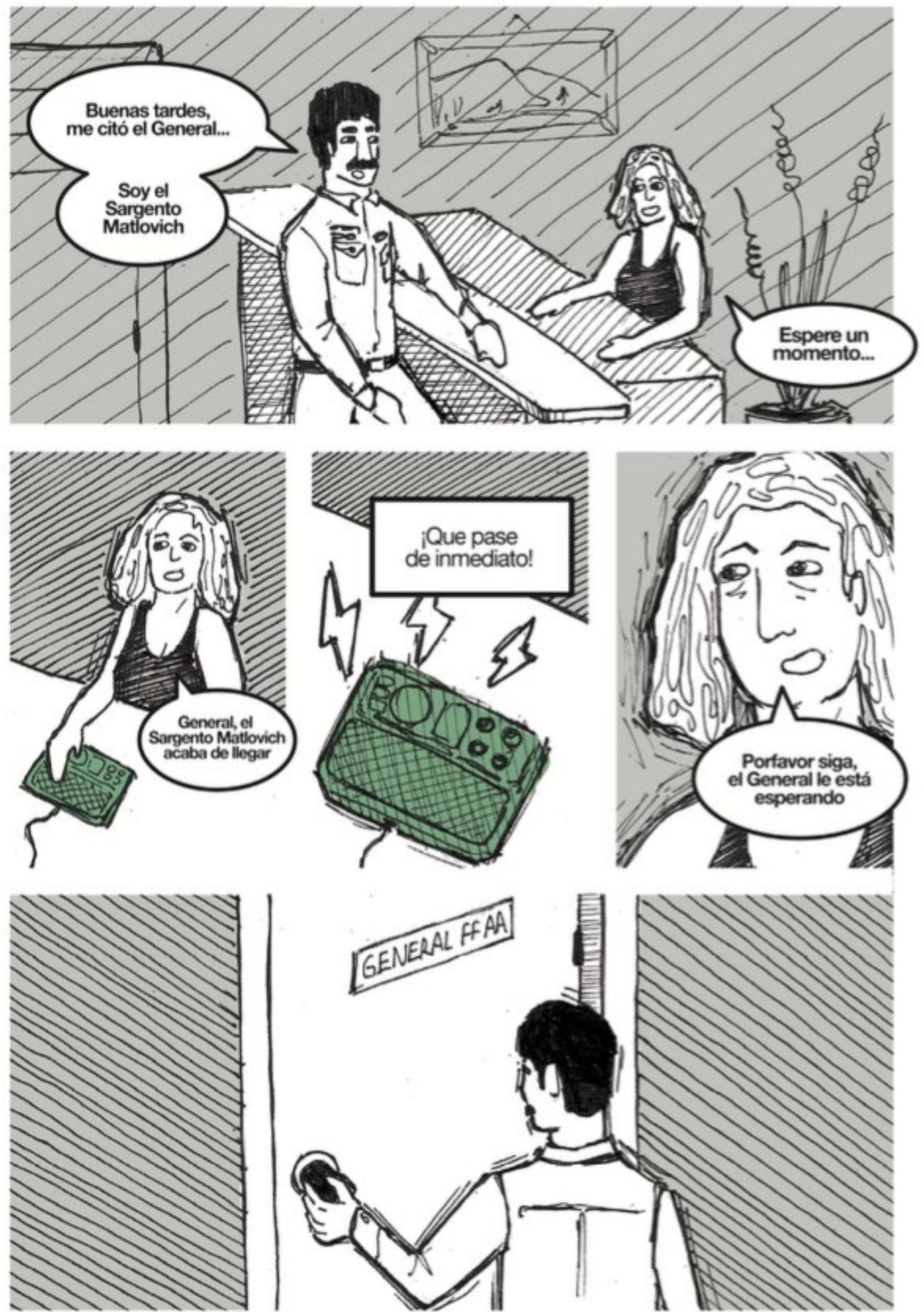

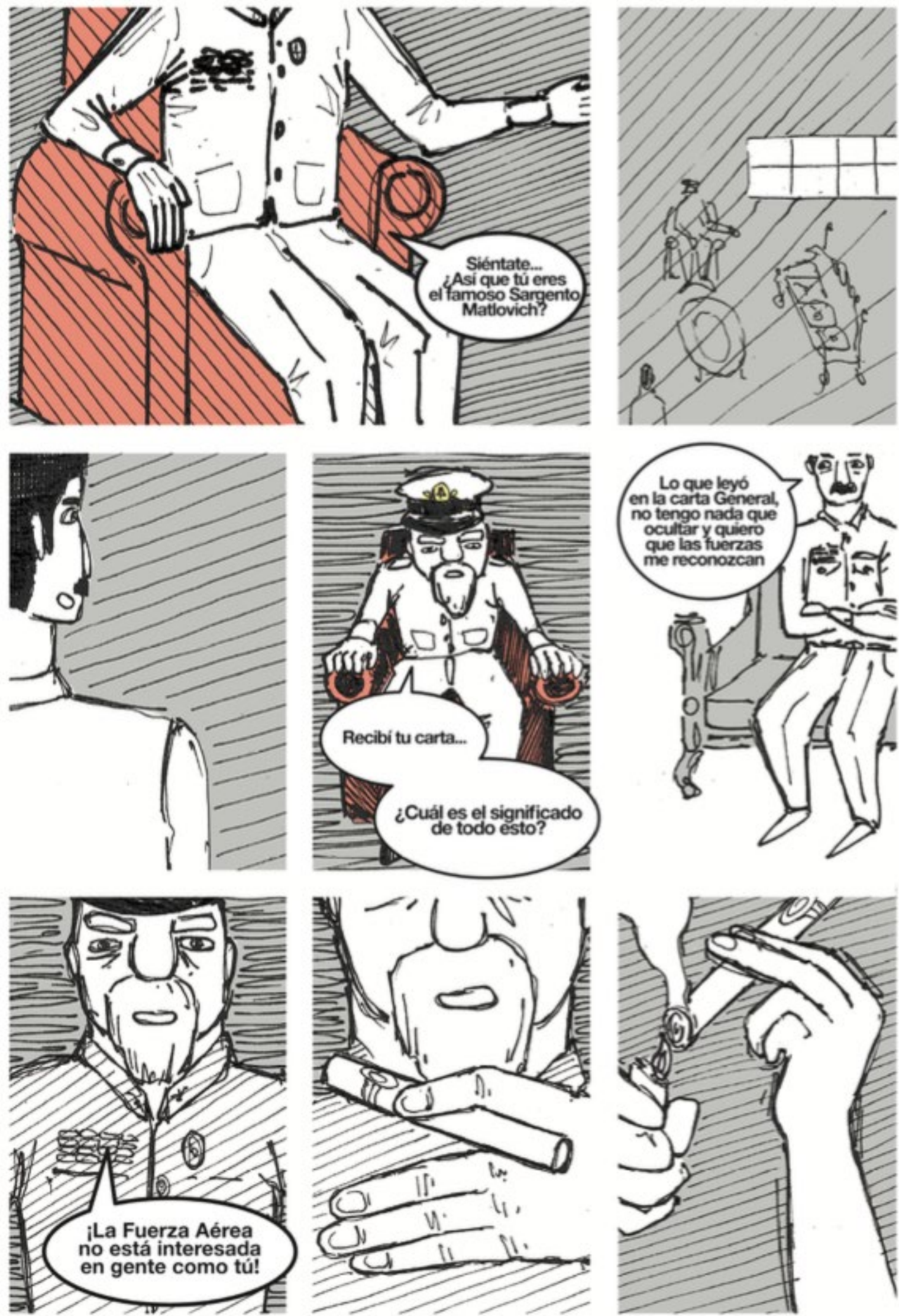

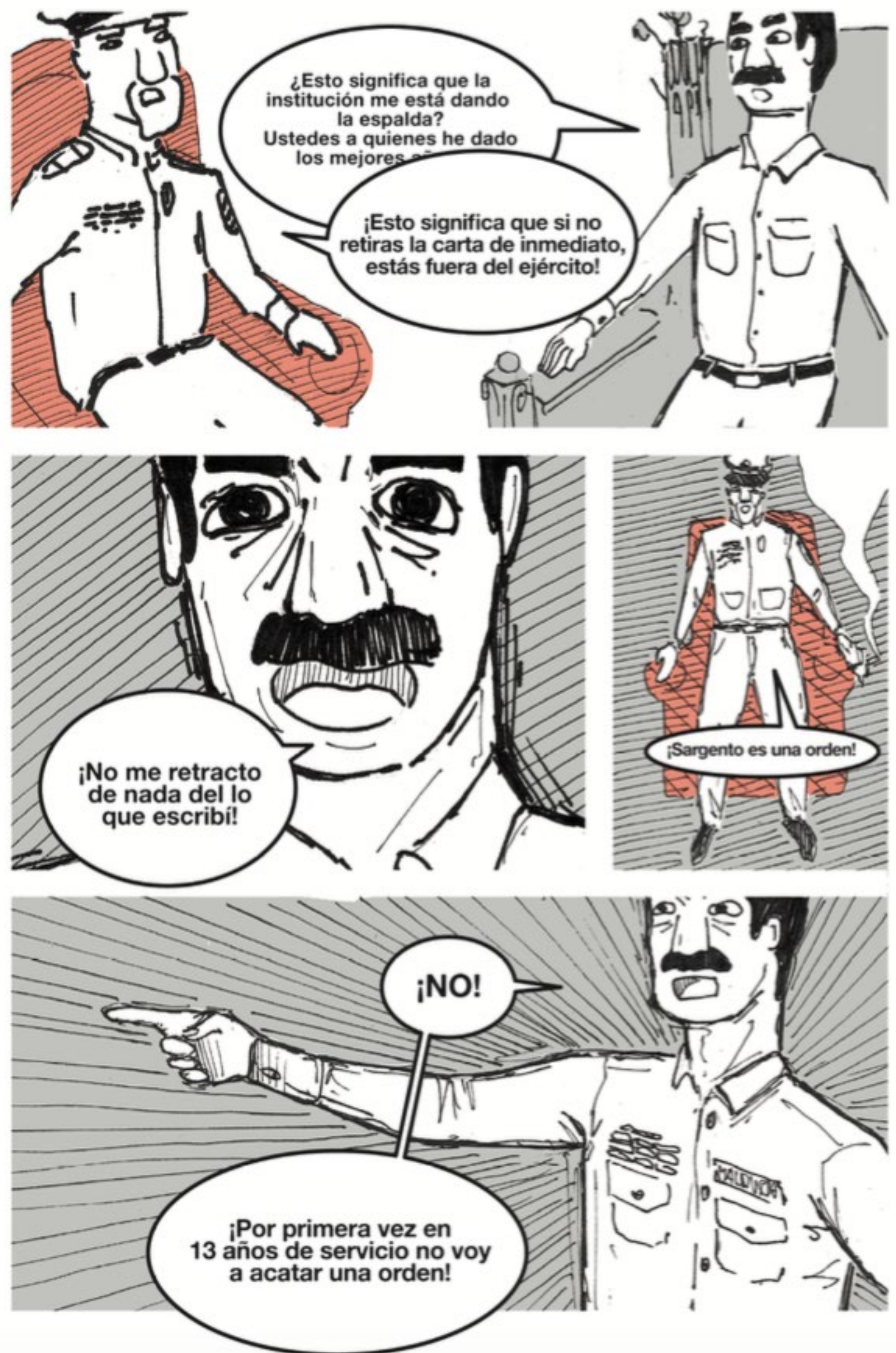

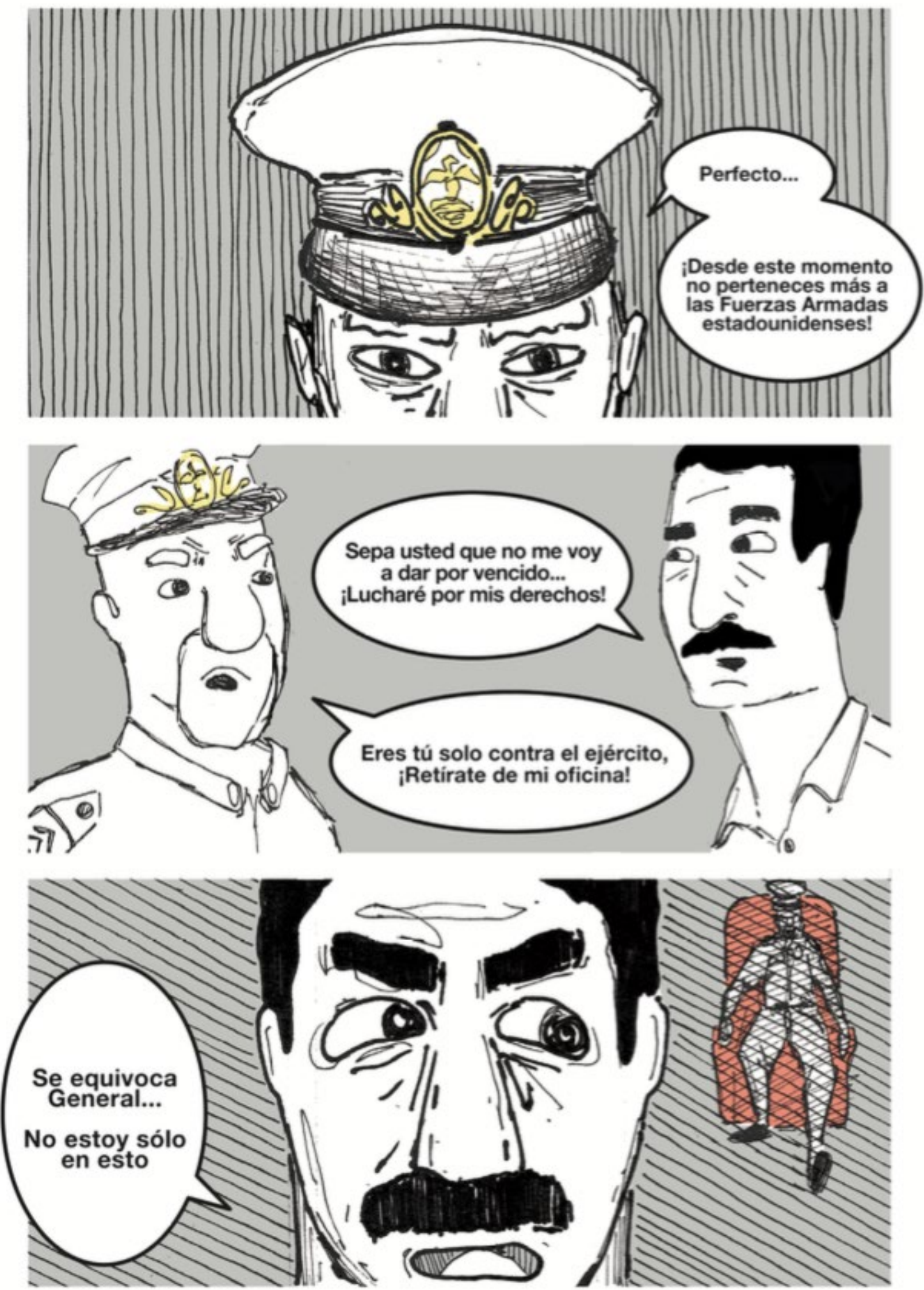


\section{Capítulo VI \\ T E LE V I S I Ó N}

Sus padres eran profundamente religiosos y muy conservadores. El padre de Mat rompió toda relación con su hijo cuando se enteró, por medio de la prensa, que el ex Sargento era homosexual.

En 1988, Matlovich hizo una última declaración pública al revelar en una entrevista televisiva, que fue diagnosticado como VIH positivo.

Su padre de inmediato lo perdonó, y Leonard Matlovich vivirá sus últimos días junto a sus seres queridos. 

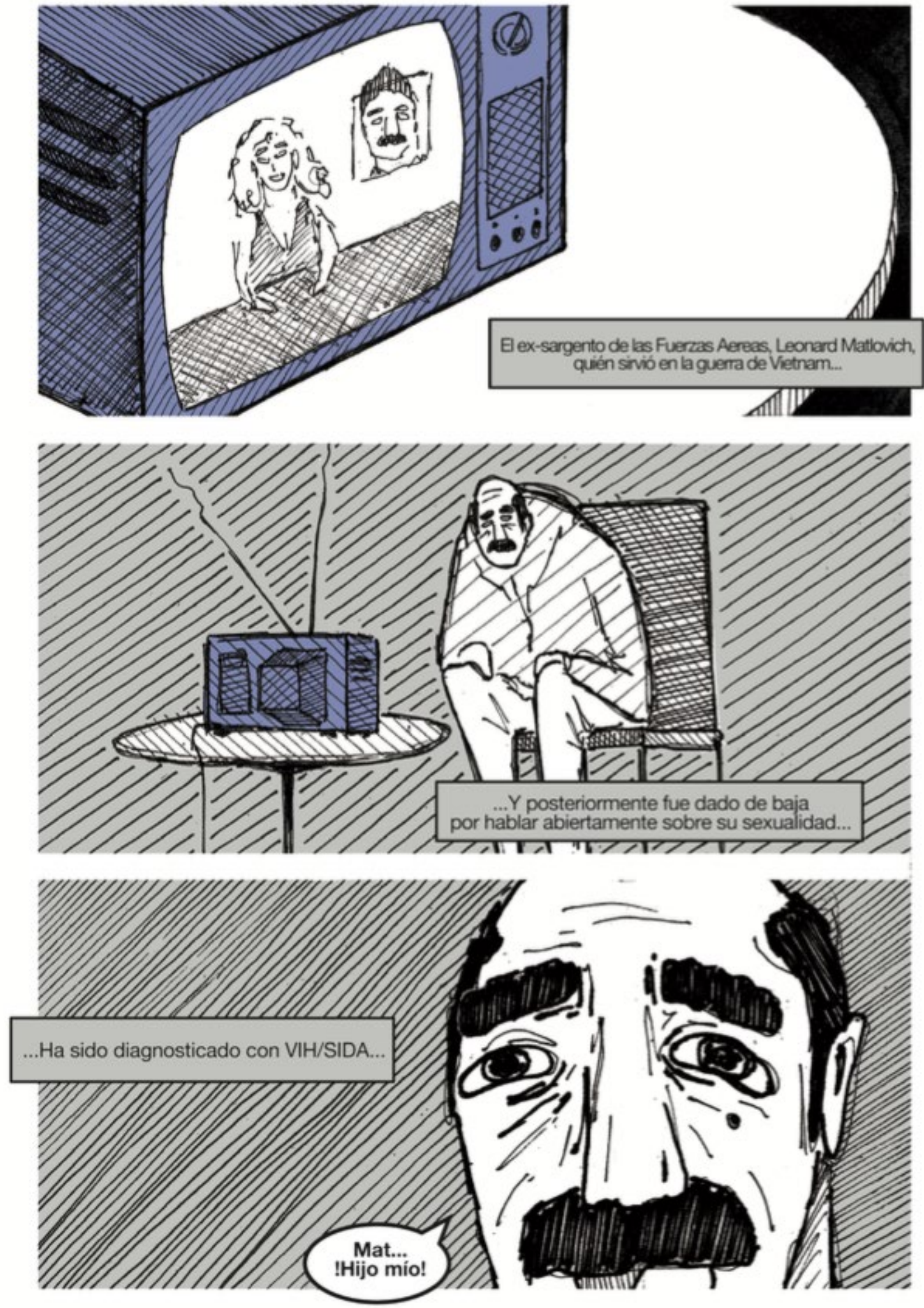

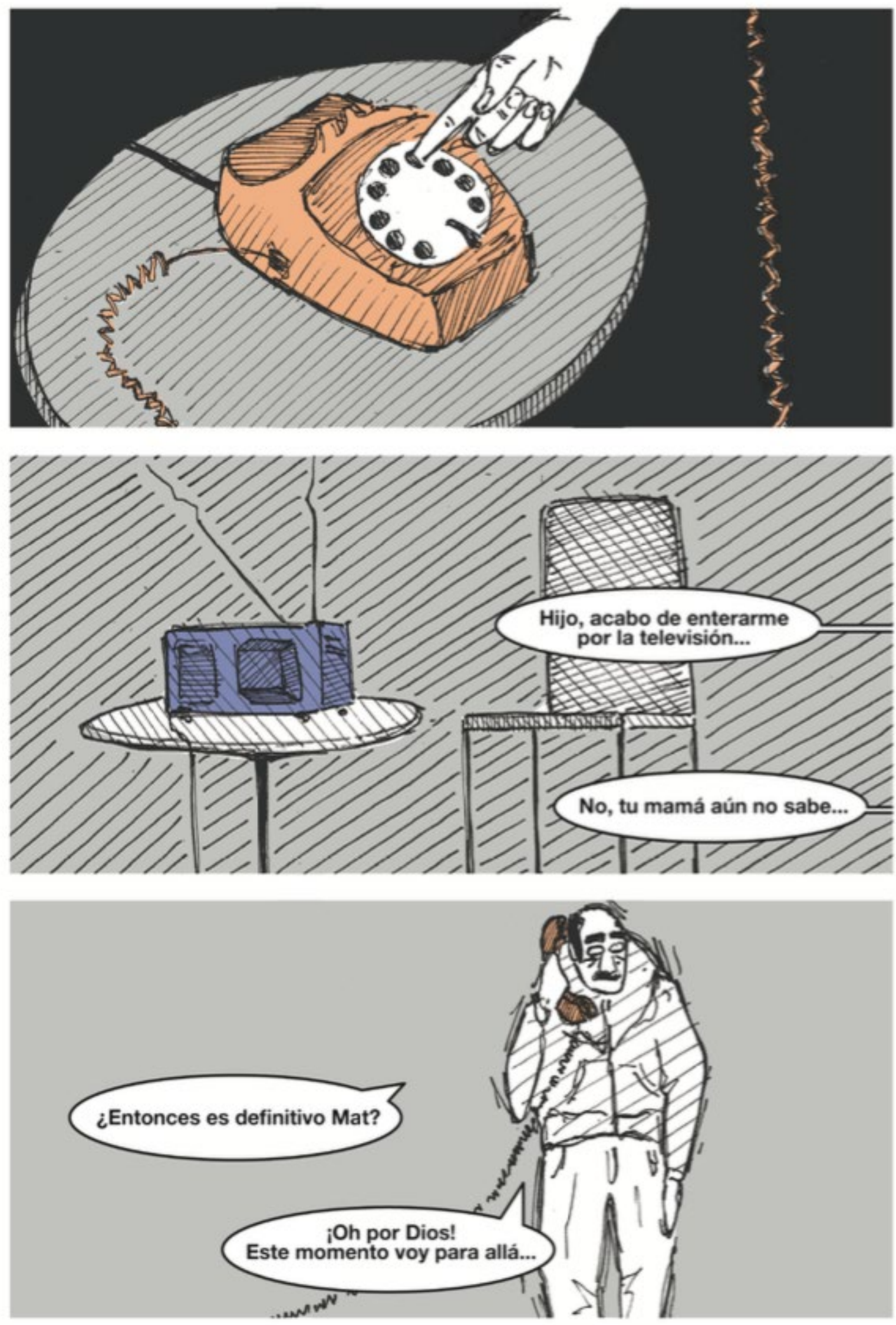
Tras cinco años de lucha, la Fuerza Aérea le ofreció un acuerdo financiero y no le readmitió en la milicia. Mat se convirtió en uno de los mayores activistas y principal responsable de la lucha por los derechos y libertades civiles del colectivo LGTBI en los Estados Unidos. El ex Sargento luchó contra la "Proposición 6", más conocida como la "Iniciativa Briggs", que fue un proyecto de ley presentado a referéndum en el estado de California (Estados Unidos) el 7 de noviembre de 1978. La iniciativa que fue rechazada, venía respaldada por el político John Briggs, legislador conservador del Condado de Orange (Orange County) de California, y pretendía prohibir a los profesores gays y lesbianas el trabajar en las escuelas públicas de California. También se opuso a la "Proposición 64" que planteaba poner en cuarentena a los gays que tenían SIDA.

En su tumba en el Cementerio Congresal de Washington puede leerse esta inscripción: "Cuando estaba en el ejército me dieron una medalla por matar a dos hombres y me dieron la baja por amar a uno". 


\section{(1943-1988) \\ Leonard P. Matlovich}

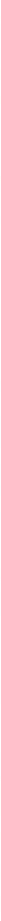



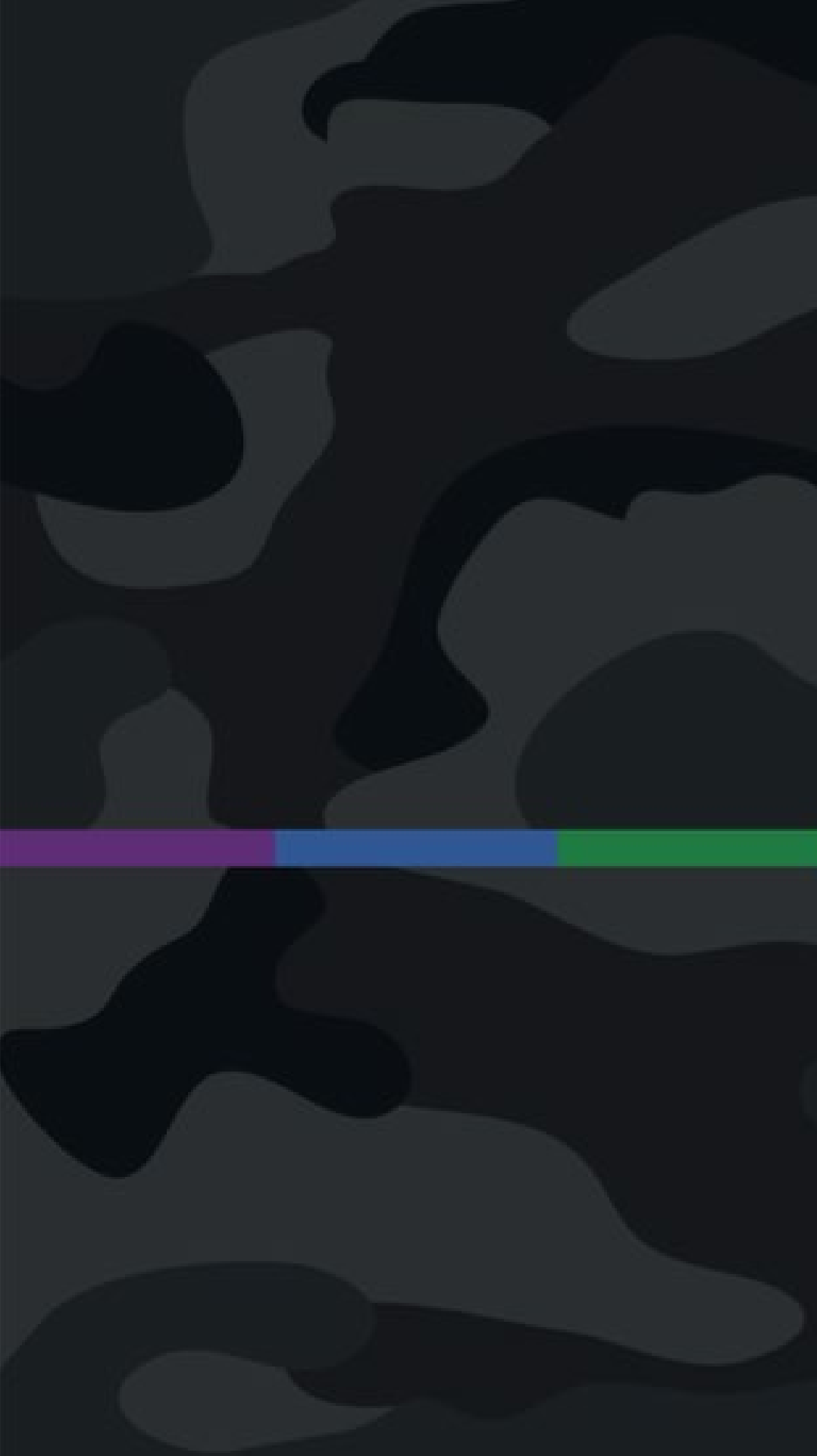


\section{Referencias}

BBC Mundo. (2013). Leonard Matlovich, el aviador gay que desafió al ejército de Estados Unidos. Recuperado de http://www.bbc.com/mundo/noticias/2013/03/130326_sociedad_eeuu_ aviador_gay_ejercito_np

Leonardmatlovich. (s/f). TSGT. Leonard Matlovich, USAF. Recuperado de http://www.leonardmatlovich.com/home.html

Michael R. Stevenson, Jeanine C. Cogan. (2003). Everyday Activism: A Handbook for Lesbian, Gay, and Bisexual People and Their Allies. Recuperado de https://books.google.com.ec/books?id=pgYcuvJvLlcG\&pg=PA147\&lpg=PA1 $47 \& \mathrm{dq}=$ Don $\% \mathrm{E} 2 \% 80 \% 99 \mathrm{t}+$ Pursue + and + Don $\% \mathrm{E} 2 \% 80 \% 99 \mathrm{t}+$ Harass\&sou rce=bl\&ots= $=$ cm3cbIJVa4\&sig $=$ kGorF_c 1 PdnWwGOUrIM3 1 o7PF78\&hl=es419\&sa=X\&ved=0ahUKEwit56_979nJAhWENSYKHXs9Dz8Q6A EIPzAG\#v= onepage \&q=Don $\%$ E $2 \% 80 \% 99 \mathrm{t} \% 20$ Pursue $\% 20$ and $\% 20$ Don $\% \mathrm{E} 2 \% 80 \% 99 \mathrm{t} \% 20$ Harass \&f $=$ false

Moradi, B. y Miller, L. (2010). Attitudes of Iraq and Afghanistan war veterans toward gay and lesbian service members. Armed Forces E Society, 36, 397-419.

Quam,K.(2015).Unfinishedbusiness of repealing “Don'tAsk,Don'tTell”: Themilitary's unconstitutionalbanontransgenderindividuals. UtahLawReview, 2015(3),721-741. 